\title{
Status of short-chain chlorinated paraffins in matrices and research gap priorities in Africa: a review
}

\author{
Vhodaho Nevondo ${ }^{1}$. Okechukwu Jonathan Okonkwo ${ }^{1}$
}

Received: 4 December 2020 / Accepted: 7 August 2021 / Published online: 3 September 2021

(C) The Author(s) 2021

\begin{abstract}
Chlorinated paraffins (CPs) have been applied as additives in a wide range of consumer products, including polyvinyl chloride (PVC) products, mining conveyor belts, paints, sealants, adhesives and as flame retardants. Consequently, CPs have been found in many matrices. Of all the CP groups, short-chain chlorinated paraffins (SCCPs) have raised an alarming concern globally due to their toxicity, persistence and long-range transportation in the environment. As a result, SCCPs were listed in the Stockholm Convention on Persistent Organic Pollutants (POPs) in May 2017. Additionally, a limit for the presence of SCCPs in other CP mixtures was set at $1 \%$ by weight. CPs can be released into the environment throughout their life cycle; therefore, it becomes crucial to assess their effects in different matrices. Although about 199 studies on SCCP concentration in different matrices have been published in other continents; however, there are scarce/or limited studies on SCCP concentration in Africa, particularly on consumer products, landfill leachates and sediment samples. So far, published studies on SCCP concentration in the continent include SCCPs in egg samples, e-waste recycling area and indoor dust in Ghana and South Africa, despite absence of any production of SCCPs in Africa. However, there still remains a huge research gap in the continent of Africa on SCCPs. Consequently, there is a need to develop robust SCCP inventories in Africa since the Stockholm Convention has already developed guidance document in this respect. This review, therefore, examines the state of knowledge pertaining to the levels and trends of these contaminants in Africa and further provides research gaps that need to be considered in order to better understand the global scale of the contaminant.
\end{abstract}

Keywords POPs $\cdot \mathrm{CPs} \cdot \mathrm{SCCPs} \cdot$ Matrices $\cdot$ Africa

\section{Introduction}

Chlorinated paraffins (CPs), also known as poly-chlorinated n-alkanes (PCAs), are complex halogenated mixtures which comprise various carbon chain lengths and chlorine atoms and are normally produced by the chlorination of n-alkane feed stocks with molecular chlorine under forcing conditions such as ultraviolet light and high temperature (van Mourik et al.

Responsible Editor: Roland Peter Kallenborn

Okechukwu Jonathan Okonkwo

OkonkwoOJ@tut.ac.za

Vhodaho Nevondo

vhodahonevondo@gmail.com

1 Department of Environmental, Water and Earth Sciences, Faculty of Science, Tshwane University of Technology, 175 Nelson Mandela Drive, Pretoria Central 0001, South Africa
2015; Wang et al. 2018a). CPs are generally hydrophobic and semi-volatile, ranging from colourless to yellowish liquids (Feo et al. 2009). The three subgroups of CPs are divided based on their carbon chain length: short-chain chlorinated paraffins ( $\mathrm{SCCPs}, \mathrm{C}_{10}-\mathrm{C}_{13}$ ), middle-chain chlorinated paraffins (MCCPs, $\mathrm{C}_{14}-\mathrm{C}_{17}$ ) and long-chain chlorinated paraffins (LCCPs, C > 18) (Wang et al. 2018a; Reth and Oehme 2004).

According to Wang (2010), CPs are mainly categorized under high production volume chemicals in comparison with other persistent organic pollutants (POPs) worldwide. The production of CPs have been increasing significantly since their introduction in the early 1930s (Feo et al. 2009). Globally, an estimation of about $>7$ million tonnes of CPs have been produced since the 1930s of which $>1$ million metric tonnes are produced per year (Wang 2010). Among other countries, China is listed as the major producer of CPs with recent annual production rates of about 1.05 million tonnes per year (van Mourik et al. 2016). Although not much information is given about the production of SCCPs in Africa, 
according to a report published in 2015, approximately 10,000 tonnes of CPs were produced per year in South Africa (ICIS 1995). In addition, a study by Babayemi et al. (2019) indicated that large volumes of PVC and other polymers with additives that can contain CPs are imported in huge quantities to African countries with major imports to Egypt, Nigeria, South Africa, Algeria, Morocco and Tunisia, e.g. under Harmonized System (HS) codes HS3901 to HS3907 and HS3917 to HS3926. In total, 33 African countries with available HS data imported approximately $86.14 \mathrm{Mt}$ of polymers in primary form and $31.5 \mathrm{Mt}$ of plastic products between 1990 and 2017 (Babayemi et al. 2019).

Because of their physico-chemical properties such as their varying carbon chain lengths and chlorine percentages, high chemical stability, flame retardance, viscosity, low vapour pressure and strength at low temperature, CPs are added during the production of different consumer products. The consumer products include coolants and lubricants used in metal working fluids, as flame retardants, in polymers mainly polyvinyl chloride (PVC) products, underground mining conveyor belts, paints, sealants and adhesives (Lassen et al. 2014; Tomy et al. 1998). SCCPs can be released into the environment throughout their life cycle, during production, use in industrial processes or production of consumer products and disposal of CP-containing products (Guida et al. 2020). Bidleman et al. (2010) also stated that sources of CPs in the environment can be classified as evaporation and combustion that include volatilization from old in-use or disposed products that contain CPs and polychlorinated biphenyls (PCBs), released during combustion of the consumer products and evaporation from contaminated soils.

Among other CP compounds, SCCPs have triggered a worldwide environmental pollution concern considering their toxicity, persistence, bioaccumulation and long-range transportation in the environment (POPRC 2015). SCCPs were listed under Annex A of Stockholm Convention on POPs in May 2017 (POPRC 2017; UNEP 2017). As decided during the eighth Conference of the Parties (COP-8), SCCPs with chain lengths ranging from $\mathrm{C}_{10}$ to $\mathrm{C}_{13}$ and a chlorine content greater than $48 \%$ by weight should be eliminated (UNEP 2017). Additionally, the content of SCCPs in other CP mixtures was limited to $1 \%$ by weight, meaning that CPs with a SCCP content $\geq 1 \%$ are now also considered POPs (UNEP 2019a, b, c). The toxicological effects of SCCPs are particularly highlighted in comparison with those of MCCPs and LCCPs (Wei et al. 2016). SCCPs were documented in the risk profile document of the Persistent Organic Pollutant Review Committee (POPRC) as compounds that may lead to significant health threats in human and animals (POPRC 2015; Wei et al. 2016). Routes of exposure to SCCPs in human include dust inhalation and dietary intake (Fridén et al. 2011). The European Chemicals Bureau (ECB) and the International Agency on Research of Cancer (IARC) have listed SCCPs as carcinogenic compounds (ECB 2007; IARC 1990). Carcinogenicity studies on exposure to CPs in animals have shown that female and male mouse treated for 103 weeks by gavage with 0.125 or $250 \mathrm{mg} / \mathrm{kg}$ bw of commercial-grade CP product dissolved in corn oil were dead at 112-114 weeks of age (IARC 1990). Wang et al. (2019b) have associated the toxicology of SCCPs with lethality, hepatotoxicity, developmental toxicity, carcinogenicity, endocrine- and metabolismdisrupting effects and the immunomodulatory effect both in animals and human.

Studies on POPs such as brominated flame retardants (BFRs), polybrominated diphenyl ethers (PBDEs), polychlorinated biphenyls (PCBs) organochlorine pesticides (OCPs) and hexabromocyclododecanes (HBCDs) in different matrices have been carried out in Africa (Asante et al. 2011; Babayemi et al. 2015; Odusanya et al. 2009; Oloruntoba et al. 2019; Sindiku et al. 2015; Mansour 2009; Nkabinde et al. 2018; Adu-Kumi-Jonathan et al. 2019; Vaccher et al. 2020; Katima et al. 2017; Sibiya et al. 2019). However, there is limited information on $\mathrm{CP}$ studies in different matrices, with the exception of the studies by Adu-Kumi-Jonathan et al. (2019), Brits et al. (2020) and Möckel et al. (2020). The scarcity of information on SCCPs in the continent can be attributed to lack of analytical capacity. Lack of chemical management, regulations and database of chemicals used could also be among other reasons. However, different studies from different continents have shown the occurrence and concentrations of SCCPs in almost all matrices such as air, water, wastewater, soil, sediment, biota, human blood and breast milk (van Mourik et al. 2016; Li et al. 2017a; Xia et al. 2017a). Additionally, considering that Africa is second to Asia in terms of size and population with increasing industrialization, population and urbanization and prone to legal and illegal imports of goods (Gioia et al. 2014), it, therefore, becomes an important study area for SCCPs. This review, therefore, examines the state of knowledge pertaining to the levels and trends of these contaminants in Africa and further provides research gaps that need to be considered in order to better understand these pollutants on a global scale. Additionally, Africa needs to assess the presence, use and life cycle of SCCPs in order to develop and update its implementation plans to control the use of POPs such as SCCPs.

\section{SCCP production, industrial uses and environmental releases}

\section{Production}

SCCPs, including other CP groups, have been produced commercially in different countries since the 1930s with some minor production already before the 1920s (Glüge et al. 2016). The global production of CPs was estimated to be 
around 20 and 165,000 tonnes per year, with the United States of America (USA) leading this production (Glüge et al. 2016; Guida et al. 2020). However, between 2006 and 2013, the global production of CPs reached alarming volumes when China took the lead, increasing its production to 260,000 tonnes per year in 2006 and 1,000,000 tonnes per year in 2013 (Guida et al. 2020; Xu et al. 2014). According to Zeng et al. (2012), more than 150 manufacturing factories of CPs are scattered throughout China, which contributes to the widespread occurrence of CPs in China. The overall production of CPs considerably increased at the end of the 1970s, when Japan and European countries began or increased production (IARC 1990; Guida et al. 2020). Wei et al. (2016) reported that SCCPs have been used as replacements for the use of PCBs in Japan; however, the production volume of SCCPs decreased to approximately 500 tonnes per annum in 2002 because of their production being regulated. Fiedler (2010) reported that countries such as South Korea have no record of SCCP production, but an estimation of about 156 tonnes was reported in 2002. India was estimated to have an annual volume production of SCCPs of about 0.11 million tonnes in 2008 (Chaemfa et al. 2014) and currently the second largest producer of CPs. Moreover, the production of SCCPs have ceased in the US, Japan, Canada and Europe. However, van Mourik et al. (2016) reported that MCCPs and LCCPs were still produced as alternatives resulting in the increase of $\mathrm{CP}$ production volume per year. The Stockholm Convention has also pointed out that CPs of various chain lengths were produced in 10 other countries (Australia, Brazil, France, Italy, Japan, Russia, Spain, Slovakia, South Africa and England) (UNEP 2019a, b, c). In Africa, according to a report published in 2015, approximately 10,000 tonnes of CPs were produced per year in South Africa (ICIS 1995). In addition to the provided information on the production of SCCPs, Table 1 shows information on countries producing SCCPs or other CPs.

\section{Industrial uses}

According to the draft guidance on preparing SCCP inventories, uses of SCCPs have varied between countries over time depending on the need of products and the regulatory frame (UNEP 2019a). SCCPs were mainly used in polyvinylchloride
(PVC) as secondary plasticizers, in rubber as flame retardants, metal-working fluids and other lubricants, paints, coatings, sealants, adhesives, textiles and leather and other plastics, such as ethylene-vinyl acetate (EVA), which also includes a range of polymeric products associated with frequent contact or indoor releases (UNEP 2019a). Studies have shown that CP mixtures, mainly SCCPs and MCCPs, are commonly found in consumer products (Gallistl et al. 2017; Brandsma et al. 2019; Yuan et al. 2017a, b; Wang et al. 2018a, b, 2019a, b, c, d, e; Xu et al. $2019 \mathrm{a}, \mathrm{b}, \mathrm{c})$. As a result, the European Union (EU) has established a regulatory limit of $1500 \mathrm{mg} \mathrm{kg}^{-1}$ for SCCPs in consumer products and $1 \%$ in other $\mathrm{CP}$ formulations. However, after screening of consumer product market in the EU and Norway from 2013 to 2017, a report to the Rapid Exchange of Information System of the European Union (RAPEX) revealed that a wide range of consumer products exceeded the limit of $1500 \mathrm{mg} \mathrm{kg}^{-1}$ (Guida et al. 2020). Furthermore, in 2013, the use of SCCPs was prohibited in the US, while the EU restricted their use in 2011. Nevertheless, SCCPs were still applied as flame retardants in conveyor belts in the mining industry and in dam sealants (ESWI 2011). Fiedler (2010) also reported that SCCPs were still applied in different consumer products at rates of about 100 ktonnes per year worldwide.

In Europe, SCCPs are mainly applied in rubber industry, followed by sealants and adhesives, paints and paint coatings and varnishes (ESWI 2011). It was reported that the consumption of SCCPs in these consumer products have increased from 638 to 1254 tonnes per year in 1998 and 713-796 tonnes per year in 2011 (ESWI 2011). In addition, SCCPs were used to replace PCBs and polychlorinated naphthalenes (PCNs) in a wide range of open applications (cables, sealants, adhesives, textiles and leather) (Howard et al. 1975), but with certain exemptions under the Stockholm Convention (Table 2). The Stockholm Convention exemptions included additives in the production of transmission belts in the natural and synthetic rubber industry, spare parts of rubber conveyor belts in the mining and forestry industries, leather industry, in particular fat-liquoring in leather, lubricant additives and for automobile engines. Other exemptions include electrical generators and wind power facilities; oil and gas exploration, petroleum refinery to produce diesel oil and tubes for outdoor decorating bulbs; waterproofing and flame-retardant paints; and
Table 1 Countries producing SCCPs or other CPs

\begin{tabular}{ll}
\hline Status of SCCP or CP production & Countries \\
\hline Production of SCCPs between 1993 and 2009 & USA, Brazil, Germany, France, the UK, Italy, Japan \\
Stopped production of SCCPs & Brazil, EU countries, Japan, Russia, United States (US) \\
Current production of CPs of various lengths & Australia, Brazil, China, France, India, Italy, Japan, \\
Never had SCCP production & Russia, Spain, Slovakia, South Africa, UK \\
\hline
\end{tabular}

Data were compiled from draft guidance on preparing inventories of SCCPs (UNEP 2019a) 
Table 2 SCCP content limits reported for their main uses.

\begin{tabular}{ll}
\hline SCCP applications & SCCP content in mg/kg \\
\hline Lubricant & Up to 700,000 (70\% weight) \\
Metal-working fluid & Up to 700,000 (70\% weight) \\
Adhesive/sealant & Up to 300,000 (30\% weight) \\
Paint & Up to 200,000 (20\% weight) \\
Leather & Up to 200,000 (20\% weight) \\
Rubber & Up to 170,000 (17\% weight) \\
Textile & Up to 150,000 (15\% weight) \\
Polyvinylchloride (PVC) & Up to 100,000 (10\% weight) \\
Ethylene-vinyl acetate (EVA) foam & Up to 70,000 (7\% weight) \\
\hline
\end{tabular}

Adapted from UNEP (2019a); Guida et al. (2020)

adhesives, metal processing and secondary plasticizers in flexible PVC, except in children's toys (UNEP 2019a; Guida et al. 2020). With the already mentioned information on the production of CPs and the import of polymers in Africa, the occurrence of CPs in different applications becomes quite clear, and the need to also develop robust SCCP inventories and regulations in Africa becomes obvious.

\section{Environmental releases}

The release of SCCPs into the environment normally occurs anthropogenically during production, industrial use and disposal of SCCP-containing consumer products (Guida et al. 2020). It is proposed that SCCPs are more likely to migrate through vapour phase, while MCCPs and LCCPs are likely adsorbed to particles like dust (Zhou et al. 2018; Brits et al. 2020). Few estimates are available for the releases and bioavailability of CPs from polymeric material lost during product service life due to evaporation or as particles during wear and abrasion of flooring, rubber products, sealants or PVC (Guida et al. 2020). However, a study from the European Commission assumed that about $8 \%$ of the SCCPs in sealants are emitted during the product lifetime which is higher than the release rate of PCBs from sealants by evaporation, approximately $0.06 \%$ per year (ESWI 2011; Weber et al. 2018). Lassen et al. (2014) reported that wastes consisting of rubber, sealants, adhesives, paints and textiles are a potential source of SCCPs entering into the environment.

While underground mining conveyor belts are considered major sources of SCCPs released into the waste stream (55\%) in Europe, followed by sealants (19.8\%) and paints (19.8\%) (ESWI 2011), it is noteworthy to consider that Africa is endowed with large reserves of mineral resources, which contributes a significant part of the economy (Campbell 2009). Since the beginning of the 1980s, the International Financial Institutions (IFIs) and developing countries have assigned a high priority to the development of mining sector to meet the goal of improving national economic conditions and ultimately reduce poverty. However, faced with the environmental and social impacts of the mining industry, these objectives have been constantly challenged (Campbell 2009). In view of this, it is, therefore, important to mention that underground mining conveyor belts are used in large quantities in the African mining industry, which contributes to the release of SCCPs from this source.

$\mathrm{Xu}$ et al. (2014) reported an estimation of about 503 and 1,290 tonnes emission of SCCPs into the atmosphere and water respectively from $\mathrm{CP}$ production and application sites in China. CPs in some applications, such as lubricants and metal-working fluids, are largely released to the environment during use (Guida et al. 2020). The usage of metal cutting fluids is listed as one of the largest sources of emission into the atmosphere (246-412 $\mathrm{t} \mathrm{year}^{-1}$ ), followed by the synthesis of PVC plasticizers (40.0-58.7 t/year) (Xu et al. 2014). SCCPs released to the environment may also occur during the use of gear oil packaging, fluids used in hard rock mining, fluids and equipment used in oil and gas exploration, manufacture of seamless pipe, metal working and operation of turbines on ships (CPIA 2002). Although a handbook prepared by the Chlorinated Paraffins Industry Association (CPIA) to promote the environmentally safe management of used oils is available, a major challenge is that waste oils are often recovered as fuel and the input of CPs to such fuels increases the risk of corrosion (PDEP 2019). Also, oils with a halogen content above $1000 \mathrm{mg} \mathrm{kg}^{-1}$ might be considered hazardous waste in some countries (PDEP 2019) or might need destruction in a hazardous waste incinerator if the halogen organic substance content is above $10,000 \mathrm{mg} \mathrm{kg}^{-1}$ (European Commission 2010).

Landfills are identified as a potential source of SCCPs released into the environment due to the occurrence of SCCPcontaining waste in landfills (Lassen et al. 2014). Release pathway of SCCPs from landfills includes leaching, run-off and volatilization (POPRC 2015; Fiedler 2010; Feo et al. 2009; Zeng et al. 2013b). According to Weber et al. (2011), POPs are released from landfills in leachates at varying degrees depending on their physical-chemical properties. SCCPs and other CPs are detected in landfill leachates at levels up to $614 \mu \mathrm{g} \mathrm{L}^{-1}$ (Weber et al. 2011). Considering the higher historical production of CPs compared to other POPs, the amount of waste containing SCCPs and other CPs and the quantity CPs released to the atmosphere is also expected to be high (Glüge et al. 2016). Reports indicated that since the use of CPs started in the 1930s, it can be assumed that a large amount of waste containing SCCPs may have been already disposed into landfills and dump sites since hazardous waste management capacity and practices were not fully developed until the 1970s (UNEP 2018; ESWI 2011). Furthermore, in developing continents, particularly in Africa, polymeric products are disposed either by landfilling or open dumping (Sibiya et al. 
2017). Studies by Babayemi et al. $(2015,2018)$ elaborated that polymeric wastes are disposed with municipal solid waste (MSW) with minimal formal recycling of approximately $10 \%$. It was further explained that there is hardly any thermal or energy recovery from waste (incinerators or cement kilns) in Africa. Thus, the by far largest share of polymeric waste ends up in dump sites or landfills (Babayemi et al. 2019).

Open burning of solid waste is also a common practice in most African countries inclusive of polymeric products (Babayemi et al. 2014). As a result of lack of effective solid waste management, mixed wastes including polymers end up in dump sites where they are burnt, resulting in the release of POPs into the environment (Oloruntoba et al. 2019). Studies have further shown that depending on the type and use, polymeric products contain a wide range of additives such as plasticizers, flame retardants, antioxidants, acid scavengers, light and heat stabilizers, lubricants, pigments, antistatic agents, slip compounds and thermal stabilizers which are used for various purposes (Geyer et al. 2017; GIA 2008; Rajaram 2009; Hahladakis et al. 2018; UNEP 2019b). Many of these additives are known to have toxic effects, and some are classified as endocrine disrupting chemicals. Several others have been listed as POPs, including PBDEs, hexabromobiphenyls (HBB), HBCD, SCCPs and the fluorinated tensides like perfluorooctanoic acid (PFOA) (Babayemi et al. 2019). These releases can therefore be regarded as sources of SCCPs and other CPs to the air, soils, industrial areas and in house dust resulting in human exposure (Fridén et al. 2011; Hilger et al. 2013; Lucattini et al. 2018).

\section{Routes of exposure and toxicity}

\section{Routes of exposure}

Considering the use of SCCPs as additives in diverse consumer applications, continuous human exposure is likely to occur from this route. The major routes of exposure to SCCPs in human include air inhalation, dust ingestion and dermal absorption (EFSA 2020). Despite the scarcity of general information on human exposure to SCCPs, it is reported that ingestion of contaminated food could be a major intake pathway (Liu et al. 2020a, b). In a study conducted by Fridén (2010), dietary intake accounts for about $85 \%$ of non-occupational exposure to SCCPs in Sweden, while the same conclusions were drawn from the studies that were undertaken in Canada and China (Gao et al. 2018). Yuan et al. (2017a, b) conducted a study on CP leaching from kitchen food blenders in the European market and reported that about $75 \%$ of the handheld food blenders tested released elevated levels of CP mixtures of all chain lengths $\left(\mathrm{C}_{6}-\mathrm{C}_{22}\right)$ which ranged from 0.10 to $120 \mu \mathrm{g}$ with potential human exposure. Since all $\mathrm{CP}$ mixtures detected had a SCCP content significantly above 1\% (4-59\%; average of 28\%), the used mixtures would also be classified as POPs (Guida et al. 2020). Various amounts of CPs were also detected in baking ovens from German kitchens (Gallistl et al. 2018). MCCP levels of up to $1000,000 \mathrm{mg} \mathrm{g}^{-1}$ were measured inside baking oven in 10 out of 21 samples (48\%), and in seven of these, oven SCCP content was below the limit of quantification meeting the European Union and Stockholm Convention requirement of a SCCP content of less than $1 \%$ in MCCP. However, in 3 cases, the SCCP content was $2.8 \%$, $5.0 \%$ and $14.4 \%$ of the total CP content (Gallistl et al. 2018). Other studies by Wang et al. (2018a, b, c) measured CP content in several consumer products with direct contact to human food (disposable tableware, beverage bottles, nursing bottles and lunch boxes) and also performed leaching test. Measured SCCP concentration ranged from 0.02 to $69 \mathrm{mg} \mathrm{kg}^{-1}$, while MCCP concentration ranged from 0.02 to $69 \mathrm{mg} \mathrm{kg}^{-1}$. Furthermore, to investigate the migration of CPs from food packaging into food, food simulants (water, 3\%; acetic acid, $15 \%$; ethanol and hexane) were used, and an average migration efficiency of $12 \%$ and $1.5 \%$ for SCCPs and MCCPs were reported, respectively. $\mathrm{SCCPs}\left(\mathrm{C}_{10}\right)$ and lower chlorinated $\left(\mathrm{C}_{6}\right.$ and $\mathrm{C}_{7}$ ) showed the highest migration. With these findings, it is important to highlight that since there is lack of CP regulations on uses in most African countries, SCCP oils might enter sensitive uses like lubricants in food production sector leading to a larger population exposed to their toxicological effects.

\section{Toxicity}

The toxicity of SCCPs has raised an alarming public concern globally leading to a number of research studies reviewed by Wang et al. (2019b). According to Dong et al. (2020), both plants and animals are susceptible to the toxic effects of SCCPs because of their bioaccumulation in the environment. A report from the European Food Safety Authority (EFSA) have explained that the detection of CPs in human blood and milk samples indicate that CPs are absorbed to some extent in humans and the detection of CPs in umbilical cord blood indicates that CPs can be transferred to the foetus (EFSA 2020). The toxicology of SCCPs have been associated with lethality, hepatotoxicity, developmental toxicity, carcinogenicity, endocrine- and metabolism-disrupting effects and the immunomodulatory effect both in animals and humans (Wang et al. 2019b; EFSA 2020). In a study conducted by Ren et al. (2018) on rats and mice administered with SCCPs for 2 years, survival rates of female mice were at $250 \mathrm{mg} \mathrm{kg}^{-1}$ day $^{-1}$ after the 100 th week, and that of rats at $312 \mathrm{mg} \mathrm{kg}^{-1}$ day $^{-1}$ after the 90th week, which were significantly less than those of respective controls. Another study by Wang et al. (2019d) demonstrated that exposure of male C57B1/6 mice to $100 \mathrm{mg} \mathrm{kg}^{-1}$ day ${ }^{-1}$ SCCPs (52\% chlorination, vehicle corn oil) for 28 days caused immune cell infiltration in the liver, which indicated a potential of liver damage although the liver weight was not 
affected. The International Agency for Research on Cancer (IARC 1990) reported that $\mathrm{C}_{10}$-SCCPs $(60 \%$ chlorination) were found to be carcinogenic to experimental animals and possibly carcinogenic to humans. Wang et al. (2019d) also demonstrated that mice exposed to $\mathrm{C}_{9-13}$-CPs (vehicle corn oil) altered the expression of cancer-related genes, implying that these cancer-related genes may be involved in SCCPinduced carcinogenicity. Furthermore, SCCPs are known to be endocrine disruptors. Treatment of male rats with chlorowax 500C and cerclor $56 \mathrm{~L}$ at $1 \mathrm{~g} \mathrm{~kg}^{-1}$ day ${ }^{-1}$ (vehicle corn oil) by gavage for 14 days significantly reduced the levels of plasma thyroid hormone (TH), 32\% and 39\% lower for free thyroxine (FT4) and 26\% and 35\% lower for total T4 (TT4), respectively (Wyatt et al. 1993). However, in contrast, these two SCCPs significantly caused $143 \%$ and $117 \%$ increase in plasma thyroid stimulating hormone (TSH) levels, respectively (Wyatt et al. 1993). With consistent observation of those previous studies, Gong et al. (2018) reported that male rats exposed to $100 \mathrm{mg} \mathrm{kg}^{-1} \mathrm{day}^{-1} \mathrm{SCCPs}$ (vehicle corn oil) for 28 days showed decreased levels of plasma FT4, free triiodothyronine (FT3) and hepatic T4 and increased levels of plasma TSH and hepatic T3.

\section{SCCP studies in different continents}

Different studies have indicated the ubiquity of SCCPs in diverse environments and matrices, including industrialized regions as well as remote areas (Bayen et al. 2006; Wei et al. 2016; Zeng et al. 2013a). SCCPs have been detected in matrices including air, water, sewage sludge, sediment, soil and biological tissues (Diefenbacher et al. 2015; Chang et al. 2016; Brandsma et al. 2017; Muscalu et al. 2017; Pellizzato et al. 2009), with majority of studies being conducted in China and Germany (van Mourik et al. 2015). While data is also emerging from other regions, to our knowledge, only the existing studies on the concentrations of SCCPs in different matrices are discussed below:

\section{Atmosphere}

Niu et al. (2020) analysed atmospheric SCCP concentration in the Yangtze River Delta in summer (June-September 2011) and winter (November 2011-February 2012) which ranged from 2.27 to $23.6 \mu \mathrm{g} \mathrm{g}^{-1}$ and 3.90 to $26.2 \mu \mathrm{g} \mathrm{g}^{-1}$, respectively. The determined SCCP concentrations were comparable with those obtained in summer and winter in other studies in China (Wang et al. 2019c; Wang et al. 2013; Li et al. 2018). Additionally, the obtained concentrations were also higher than those obtained in Japan and South Korea ( $\mathrm{Li}$ et al. 2012), India and Pakistan (Chaemfa et al. 2014) and Switzerland (Diefenbacher et al. 2015). Another recent study by Liu et al. (2020a) analysed SCCP concentration in $\mathrm{PM}_{2.5}$ samples from Chinese cities, and $\Sigma \mathrm{SCCP}$ concentrations in 10 cities were $19.9 \pm 41.1 \mathrm{ng}\left(1.98-274 \mathrm{ng} \mathrm{m}^{-3}\right)$. Compared with previous atmospheric SCCP concentration, only Huang et al. (2017) and Li et al. (2019) reported SCCP concentration in $\mathrm{PM}_{2.5}$ samples. Globally, the obtained results were generally higher than those in Japan, South Korea, India, UK and Norway (Borgen et al. 2002; Barber et al. 2005; Li et al. 2012; Chaemfa et al. 2014). Wang et al. (2018b) also determined SCCP concentration in air samples from farmlands and villages surrounding the $\mathrm{CP}$ production plant in China. SCCP concentration in gas phase and particle phase ranged from 82 to $316 \mathrm{ng} \mathrm{m}^{-3}$ and 7 to $17 \mathrm{ng} \mathrm{m}^{-3}$, respectively, and $\sum \mathrm{SCCP}$ concentrations in air samples were lower as the distance from the CP plant increased. In Australia, van Mourik et al. (2020b) determined SCCP concentration in ambient air samples from urban (UR), rural (RU) and remote areas (RE). SCCP concentrations in the gas phase from samplers deployed at two remote sites $\left(\mathrm{RE}_{1-2}\right)$ were below MDL and if $\sum \mathrm{SCCP}$ concentration above MDL, ranged from $11\left(\mathrm{RU}_{5}\right)$ to $170\left(\mathrm{RU}_{1}\right) \mathrm{ng} /$ sampler with $\sum$ SCCP concentration of $61 \mathrm{ng} /$ sampler. The $\sum$ SCCP concentrations were 28 -fold higher than those of PCBs measured with the same sampler at the same site in 2012 (Wang et al. 2015).

\section{Indoor dust}

Brits et al. (2020) analysed short-, medium- and long-chain chlorinated paraffins in indoor dust in South Africa. ¿SCCP concentrations in freshly collected dust samples were $17 \mu \mathrm{g}$ $\mathrm{g}^{-1}$ and $14 \mu \mathrm{g} \mathrm{g}^{-1}$ in dust samples collected from household vacuum cleaner bags. The obtained concentrations were higher than those from studies conducted in Australia, Canada, Germany and Sweden (He et al. 2019; Shang et al. 2019; Hilger et al. 2013; Wong et al. 2017) and lower than those from Australia, China and the UK (Wong et al. 2017; Chen et al. 2018; Liu et al. 2017; Shi et al. 2017). Chen et al. (2016) developed a method for extracting SCCPs from indoor dust samples in Taiwan. In application of the method, SCCP concentrations were detected in all indoor dust samples with concentrations ranging from 1.2 to $31.2 \mu \mathrm{g} \mathrm{g}^{-1}$. The determined concentrations were similar with those reported by Fridén et al. (2011) and Hilger et al. (2013).

\section{Aquatic environment}

According to Houde et al. (2008), SCCPs released during production and use have entered water bodies and have been transferred to sediment and aquatic organisms resulting in bioaccumulation through the food chain. Globally, bioaccumulation and trophic magnification of SCCPs have been studied (Houde et al. 2008; Li et al. 2017a; Ma et al. 2014b; Sun et al. 2017; Zeng et al. 2017a). In the aquatic environment, SCCPs are more likely to be adsorbed in sediment since they 
have low water solubility and high carbon partition coefficients (Environment Canada 2008). There are quite a number of studies that have been reported globally (Wang et al. 2019a; Pan et al. 2018; Pan et al. 2020; Huang et al. 2019a; Wang et al. 2020a; Labadie et al. 2019).

\section{River water}

Pan et al. (2020) conducted a study in April 2014 to determine SCCP concentration in a river-estuary system in China. SCCP concentration ranged from ND to $470 \mathrm{ng} / \mathrm{L}$ with $\sum \mathrm{SCCP}$ concentration of $43 \mathrm{ng} \mathrm{L}^{-1}$, and $\mathrm{C}_{10}$ and $\mathrm{C}_{11}$ groups were dominant congener groups in the dissolved phase. The obtained highest SCCP concentration of $470 \mathrm{ng} \mathrm{L}^{-1}$ was much higher than those obtained from the influent waters of the municipal sewage treatment plants in Beijing and Japan (Wei et al. 2016; Zeng et al. 2013b). Wang et al. (2019a) reported $\sum$ SCCP concentration ranging from 15.0 to $1640 \mathrm{ng} \mathrm{L}^{-1}$ in river water samples. The results obtained were comparable to those obtained from other studies in China (Chang et al. 2016) but were also higher than in other studies (Zeng et al. 2011b; Sun et al. 2017; Houde et al. 2008; Coelhan 2010; Gandolfi et al. 2015). Huang et al. (2019a) also reported SCCP concentration in seawater samples in August 2012 from the Pearl River Estuary, South China. SCCP concentration ranged from 180 to $460 \mathrm{ng} \mathrm{L}^{-1}$ with $\sum \mathrm{SCCP}$ concentration of $270 \pm 66 \mathrm{ng}$ $\mathrm{L}^{-1}$ which were higher than the concentrations reported by Ma et al. (2014a), but much lower than those reported by Nicholls et al. (2001) while comparable to those reported by Wang et al. (2019a).

\section{Sediment}

A study was conducted by Wang et al. (2019a) in May 2016 in river water and sediments in Shanghai, China. The $\Sigma$ SCCP concentrations in sediments were in the range of not detected (ND)-2020 ng g ${ }^{-1}$. The obtained concentrations were lower than those obtained in other studies while similar to the ones obtained in some (Chen et al. 2011; Gao et al. 2012; Sun et al. 2017; Xu et al. 2019b; Zeng et al. 2017b; Qiao et al. 2016), whereas higher in comparison with two studies (Qiao et al. 2017; Iozza et al. 2008). However, the Mann-Whitney $U$ test indicated that MCCP concentrations in sediments were higher than those of SCCPs $(p<0.001)$, which was attributed to the use pattern of commercial CP formulations in China. Thus, Shanghai aquatic system is mainly contaminated by MCCPs than SCCPs. Another study by Pan et al. (2018) determined SCCP concentration in sediments from industrial, urban and rural areas of the Laizhou Bay, North China, from 14 September 17 to October 2009. SCCP concentration ranged from 8.4 to $2000 \mathrm{ng} \mathrm{g}^{-1}$ with $\sum \mathrm{SCCP}$ concentration of $160 \mathrm{ng}$ $\mathrm{g}^{-1} \mathrm{dw}$. In comparison with other studies, the results were similar to those obtained from previous studies (Pan et al. 2011a; Pan et al. 2011b), which confirmed that emissions from local factories were likely the main source of SCCPs in river sediment. Qiao et al. (2017) also determined SCCP concentration in sediments from 13 locations in the middle reaches of the Yangtze River, which ranged from 4.19 to $41.6 \mathrm{ng} \mathrm{g}^{-1} \mathrm{dw}$ and chlorine contents ranging from 61.8 to $63.8 \%$. The obtained results were similar to those of Zeng et al. (2012) and Zeng et al. (2013a), but lower than those obtained by Gao et al. (2012) and Ma et al. (2014a). Furthermore, SCCP concentrations were higher in sediment samples collected from industrialized cities where electronics manufacturing, plastic factories and petrochemical plants are located. Factors such as population density and human activities play a major role in the use and disposal of CPs; therefore, the concentrations of SCCPs are expected to be higher in urban areas than in rural areas.

In Central Europe, from July 2003 to January 2004, Přibylová et al. (2006) determined SCCP concentration in selected riverine sediments from 11 rivers (Labe, Bilina, Ohre, Vltava, Jihlava, Dyje, Svitava, Morava, Becva, Mala Becva and Drevnice) of the Czech Republic. Highest SCCP concentration of $89 \mathrm{ng} \mathrm{g}^{-1}$ was detected in sediment samples from Ohre River, which was influenced by a local factory where a range of crimping connectors and lugs for aluminium or copper cables are produced. Other SCCP sources to the Ohre River included the chemical factory where water-based dispersion and polymers are produced which is located close to the river. Additionally, other studies have indicated SCCP concentration of up to $19 \mu \mathrm{g} \mathrm{g}^{-1} \mathrm{ww}$ and $10 \mu \mathrm{g} \mathrm{g}^{-1}$ in sediment samples from Norway and Japan, respectively (Boreen et al. 2003).

\section{Soil}

Wu et al. (2020) collected soil samples in June 2018 from CP production plant brownfield site in China. $\Sigma \mathrm{SCCP}$ concentrations were detected at ND-5090 $\mathrm{ng} \mathrm{g}^{-1} \mathrm{dw}$ which indicated that CP production caused soil contamination of SCCPs. Only two studies were comparable with the obtained results (Xu et al. 2016; Wang et al. 2018b). The obtained results were also much higher than those reported by Bogdal et al. (2017), Wang et al. (2014) and Zeng et al. (2011a). SCCP concentrations ranging from 37.5 to $995.7 \mathrm{ng} \mathrm{g}^{-1} \mathrm{dw}$ in soil samples from a chemical industrial park were also determined by Huang et al. (2020), which were lower than the concentrations determined in Spain and Yangtze River Delta (Castells et al. 2008; Chen et al. 2011). Wang et al. (2020a) reported SCCP concentration in soil samples ranging from 79 to $948 \mathrm{ng} \mathrm{g}^{-1}$ with $\sum \mathrm{SCCP}$ concentration of $348 \mathrm{ng} \mathrm{g}^{-1}$. Zhao et al. (2019) also reported $\Sigma$ SCCP concentration in coastal soil samples from Shandong Peninsula ranging from 50.06 to $266.3 \mathrm{ng} \mathrm{g}^{-1}$. 


\section{Fish}

Wang et al. (2020b) reported SCCP concentration in coral reef fish from the Nansha Islands, South China Sea. SCCP concentration in fish samples from Zhubi Reef and Yongshu Reef ranged from 37.9 to $20.200 \mathrm{ng} / \mathrm{g}$ lipid weight (lw) and 75.7$25.400 \mathrm{ng} \mathrm{g}^{-1} \mathrm{lw}$, with $\sum \mathrm{SCCP}$ concentration of $3700 \pm$ $6000 \mathrm{ng} \mathrm{g}^{-1} \mathrm{lw}$ and $5200 \pm 7340 \mathrm{ng} \mathrm{g}^{-1} \mathrm{lw}$, respectively. Different studies have shown that the lipid content is a crucial factor affecting SCCP bioaccumulation in marine environment (Yuan et al. 2012; Ma et al. 2014b; Zeng et al. 2017a). In contrast, the obtained results were different from those of Pearl River Estuary, where lipid level was not the predominant influencing factor for SCCP concentration in marine organism (Huang et al. 2019). Another study by Huang et al. (2019b) has shown SCCP concentration in fish samples from the Pearl River Delta and Yangtze River Delta. The concentrations of SCCPs in farmed freshwater fish and wild sea fish ranged from 220 to $51000 \mathrm{ng} \mathrm{g}^{-1}$ lw and 900 to $7300 \mathrm{ng} \mathrm{g}^{-1}$ with $\sum \mathrm{SCCP}$ concentration of $5900 \pm 8100 \mathrm{ng} / \mathrm{g} \mathrm{lw}$ and $3000 \pm$ $1600 \mathrm{ng} / \mathrm{g} \mathrm{lw}$, respectively. Labadie et al. (2019) determined SCCP concentration in fish samples from the Rhone River basin, France. SCCP concentration ranged from 0.3 to $10.6 \mathrm{ng} \mathrm{g}^{-1}$ wet weight (ww) which were in the same order of magnitude with those reported by Saborido Basconcillo et al. (2015), Herzke et al. (2013) and Parera et al. (2013).

\section{Eggs}

In Africa, Adu-Kumi-Jonathan et al. (2019) analysed egg samples from Agbogbloshie and Accra supermarket, which was the first SCCP analysis in eggs from Africa. SCCP concentration ranged from 62 to $2067 \mathrm{ng} \mathrm{g}^{-1}$. Compared with SCCP concentration from China, the concentrations were much lower. Zeng et al. (2016) determined SCCP concentration in goose egg samples ranging from ND to $150000 \mathrm{ng} \mathrm{g}^{-1}$ $1 w$ in South China. Another study by Martínez Prats (2015) analysed SCCP concentration in gull eggs of two species (Larus michahellis and Larus audouinii) from three natural protected areas in Spain (Delta del Ebro Natural Park; Montgrí, Illes Medes i Baix Ter Natural Park; and Islas Atlánticas de Galicia Natural Park). SCCP concentration determined in egg samples of Larus michahellis ranged from 1.78 to $3.70 \mathrm{ng} \mathrm{g}^{-1}$ ww, which were notably lower than those that were determined in Larus audouinii ranging from 4.40 to $5.08 \mathrm{ng} \mathrm{g}^{-1}$ ww. Morales et al. (2012) also conducted a study in gull eggs of two species (Larus michahellis and Larus audouinii) from the Ebro delta Natural Park, and SCCP concentrations were detected at $4536 \pm 40 \mathrm{pgg}^{-1} \mathrm{ww}$ in Larus michahellis and $6364 \pm$ $20 \mathrm{pg} \mathrm{g}^{-1} \mathrm{ww}$ in Larus audouinii.

\section{Consumer products}

According to Gallistl et al. (2017), recent studies on SCCPs in consumer products have shown their occurrence and concentrations in different ranges. Guida et al. (2020) also confirmed that the most available data on CPs in consumer products are for SCCPs (Table 3). In China, Wang et al. (2018a) conducted a CP concentration study in domestic polymeric products, and highest SCCP concentration of up to $19 \%$ of the product weight was determined in PVC cable sheaths and an average mass fraction of $8.4 \%$ in cable sheaths and $0.25 \%$ in PVC floorings. SCCP mean concentrations of about $1.3 \%$ were also determined in PVC products and rubber samples originating from rubber tracks, tyres and conveyor belts, which exceeded the limit proposed by the Stockholm Convention (Wang et al. 2018a). Furthermore, the Rapid Exchange of Information System of the European Union (RAPEX) determined highest concentration of SCCPs in squeeze toy which is commonly mouthed by children of about $100.00 \mathrm{mg} \mathrm{kg}^{-1}-10 \%$ of the product weight (UNEP 2018). Extremely high concentrations of SCCPs which exceeded the European Union and the Stockholm Convention regulating limits were detected in different consumer products such as sport equipment (exercise tube), plastic bath toy, yoga mats, breastfeeding pillow and selfie stick cord of about $90,000 \mathrm{mg}$ $\mathrm{kg}^{-1}, 71.00 \mathrm{mg} \mathrm{kg}^{-1}, 69.00 \mathrm{mg} \mathrm{kg}^{-1}, 60.00 \mathrm{mg} \mathrm{kg}^{-1}$ and $45.700 \mathrm{mg} \mathrm{kg}^{-1}$, respectively (UNEP 2018). Another study that was conducted on CP leaching from kitchen blenders in

Table 3 SCCP concentrations in consumer products

\begin{tabular}{ll}
\hline Consumer product sample & SCCP concentrations $\left(\mathrm{mg} \mathrm{kg}^{-1}\right)$ \\
\hline PVC (12) & $78(30-3500)$ \\
Cables and cards (15) & $13.611(1,100-45,700)$ \\
Covers and packing (8) & $15.737(2,600-60,000)$ \\
Leather (artificial) (13) & $3954(1,100-14,000)$ \\
Sports equipment (18) & $19.056(1,800-90,000)$ \\
Stickers (5) & $11.600(2,000-18,000)$ \\
Toys (20) & $26.893(1,900-100,00)$ \\
Domestic products (19) & $11.032(700-47,000)$ \\
PVC (21) & $40.770(\mathrm{ND}-13,144)$ \\
Rubber & $614(\mathrm{ND}-13,144)$ \\
PET (19) & $0.2(\mathrm{ND}-3)$ \\
PE (5) & $0.1(0.02-0.3)$ \\
PP (18) & $4(\mathrm{ND}-69)$ \\
Food packaging (20) & $2(0.01-8.3)$ \\
Rubber track products (15) & $3639(14-12,800)$ \\
Adhesives & $3344(62-7,140)$ \\
Rubber granulate (10) & $3(\mathrm{ND}-24)$ \\
Car tires & $1(\mathrm{ND}-2)$ \\
\hline
\end{tabular}

$N D$ not detected; data were compiled from a table by Guida et al. (2020) 
the European market reported that $75 \%$ of the hand-held food blenders tested released high concentrations of CP mixtures ranging from 0.10 to $120 \mu \mathrm{g}$ of all chain length (Yuan et al. 2017b).

\section{Landfill sites and open dumping sites}

Guida et al. (2020) stated that the landfill environment forms part of a research gap in CP studies in environmental samples that needs to be investigated and assessed. Considering the fact that at the end of their life cycle, SCCP-containing consumer products normally enter the waste stream as part of municipal solid waste (MSW), the landfill environment becomes another important source of release of SCCPs into the environment that should be studied. Li et al. (2020) conducted a study in landfill soils of the Tibetan Plateau, and the concentrations of SCCPs ranged from 56.8 to $1348 \mathrm{ng} \mathrm{g}^{-1} \mathrm{dw}$ and $\sum$ SCCP concentration at $434 \mathrm{ng} \mathrm{g}^{-1}$. In that study, the highest concentration of SCCPs of about $1348 \mathrm{ng} \mathrm{g}^{-1}$ was determined from soils inside the Lhasa landfill which was attributed to the inappropriate disposal of SCCP-containing waste. In another study, high concentrations of SCCPs were determined in landfill sediment from different locations in the south of Norway, which ranged from 330 to $19.400 \mathrm{ng} \mathrm{g}^{-1}$, which was due to the deposition of waste from mechanical engineering or shipping industries (Borgen et al. 2003). Furthermore, a number of studies conducted on landfills in China have focused on SCCP concentration that are determined in soil and sediment samples of e-waste dismantling areas than in landfill leachate and sediment samples. Different research studies have shown that concentrations of SCCPs in e-waste dismantling areas are significantly higher than in other sampling areas (Kalinowska et al. 2019). Yuan et al. (2017a) determined the highest concentrations of SCCPs in soils of an e-waste dismantling area, and $\sum$ SCCP concentration ranged from 30.4 to $530 \mathrm{ng} \mathrm{g}^{-1} \mathrm{dw}$. $\mathrm{Xu}$ et al. (2019b) determined concentrations of SCCPs in soil and sediment samples of an e-waste dismantling area as well. SCCP concentration ranged from 68.5 to $2.20 \times 10^{5} \mathrm{ng} \mathrm{g}^{-1}$ and 32.5 to $1.29 \times 10^{4} \mathrm{ng} \mathrm{g}^{-1}$, respectively. Concentrations of SCCPs in soil samples were higher than in sediment samples, which were attributed to the distance between sampling points around the e-waste dismantling centres. Concentrations of SCCPs in soil and sediment samples may vary based on factors such as land-use type, proximity to sources and soil profile (Kalinowska et al. 2019).

According to Möckel et al. (2020), it can be assumed that domestic e-waste and industrial wastes are disposed of at ordinary municipal waste sites in developing countries. Möckel et al. (2020) investigated soil pollution at a major e-waste recycling site in West Africa. SCCP concentrations ranging from 69 to $1600 \mathrm{ng} \mathrm{g}^{-1}$ and 145 to $28.000 \mathrm{ng} \mathrm{g}^{-1}$ were determined in Kingtom and Agbogbloshie e-waste waste sites, respectively. Compared to literature data, the lowest SCCP concentration determined in the Agbogbloshie and Kingtom samples was similar to slightly higher than concentrations determined in ambient soils in China, UK and Norway (Xu et al. 2016; Halse et al. 2015). However, the highest SCCP concentration in Kingtom samples was similar to concentrations reported in farmland soils irrigated with wastewater and soils close to CP production plant (Zeng et al. 2011a), whereas the highest concentrations determined in Agbogbloshie samples were similar to those recently published in China $\mathrm{Xu}$ et al. 2019b). To date, there are no study reports on concentrations of SCCPs in landfill leachates.

\section{Humans}

According to Xia et al. (2017b), there is a concern about the presence of environmental pollutants in human breast milk because the pollutants could negatively affect the health of breastfeeding infants. In pregnant women, SCCPs normally accumulate in their blood and milk and then transmit to their foetus through either placental transfer or breastfeeding transfer (Aamir et al. 2019; Yang et al. 2018; Lyche et al. 2015). Due to their immature metabolism, infants are more vulnerable than older humans to potentially harmful chemicals (Darnerud et al. 2001).

\section{Breast milk}

Recently, Liu et al. (2020b) reported $\sum$ SCCP concentration of about $30.3 \mathrm{ng} \mathrm{g}^{-1} \mathrm{ww}$ in breast milk samples from China. Compared with other studies, the concentrations were of the same magnitude with those reported by Yang et al. (2018). Xia et al. (2017a) also determined SCCP concentration in breast milk samples in 2007 and 2011 in rural China. ¿SCCP concentration ranged from 68.0 to $1580 \mathrm{ng} \mathrm{g}^{-1} \mathrm{lw}$ and 65.6 to $2310 \mathrm{ng} \mathrm{g}^{-1} \mathrm{lw}$ in 2007 and 2011, respectively. The obtained results varied by about three orders of magnitude. Cao et al. (2017) also determined SCCP concentration in breast milk samples from Beijing which ranged from below the method detection limit, MDL <20-54 $\mathrm{ng} \mathrm{g}^{-1} \mathrm{lw}$. In the UK, Thomas et al. (2006) determined SCCP concentrations in human breast milk that ranged from $<71$ to $820 \mathrm{ng} \mathrm{g}^{-1}$ lw.

\section{Human serum}

Liu et al. (2020b) reported $\sum$ SCCP concentration in maternal and placenta human serum samples of about $117.1 \mathrm{ng} \mathrm{mL}$ and $70.0 \mathrm{ng} \mathrm{mL}^{-1}$, respectively, which were in the same range with those reported by Aamir et al. (2019) and Qiao et al. (2018). Ding et al. (2020) also determined SCCP concentration in serum samples of about $107 \mathrm{ng} \mathrm{g}^{-1} \mathrm{ww}$, which were comparable with those previously reported in blood samples (Qiao et al. 2018). SCCP concentrations in serum samples 
Table 4 SCCP studies in various matrices

\begin{tabular}{|c|c|c|c|}
\hline Matrices & & Sites and time of sample collection & Concentrations \\
\hline \multirow[t]{19}{*}{ Atmosphere } & Dust & $\begin{array}{l}\text { Plastic tracks and basketball courts in Beijing, China, } \\
2015\end{array}$ & 5429 and $5139 \mu \mathrm{g} / \mathrm{g}$ \\
\hline & $\begin{array}{l}\text { Indoor } \mathrm{PM}_{10}, \mathrm{PM}_{2.5} \text { and } \mathrm{PM}_{1.0} \\
\text { samples }\end{array}$ & Beijing, China, 2016 & $\begin{array}{l}38.3-87.7 \text { (mean: } 61.1), 16.8-49.4 \text { (mean: } 31.4 \text { ) } \\
\text { and } 6.4-32.5 \text { (mean: } 20.7) \mathrm{ng} / \mathrm{m}^{3} \text {, respectively }\end{array}$ \\
\hline & Indoor dust and air & Beijing, China, 2016 & $82 \mathrm{~g} / \mathrm{g}$ and $80 \mathrm{ng} / \mathrm{m}^{3}$, respectively \\
\hline & Dust falls & $\begin{array}{l}\text { A Chinese building mall and central air conditioner } \\
\text { filter dusts from a newly opened Chinese shopping } \\
\text { mall in Dalian, China, } 2015\end{array}$ & $\begin{array}{l}6.0 \text { to } 361.4 \mu \mathrm{g} / \mathrm{g} \text { and } 114.7 \text { to } 707.0 \mu \mathrm{g} / \mathrm{g} \text {, } \\
\text { respectively }\end{array}$ \\
\hline & Air & Dalian, China, in 2010 and 2016 & $\begin{array}{l}15.12 \text { to } 66.44 \text { (mean: } 30.26) \mathrm{ng} / \mathrm{m}^{3} \text { and } 65.30 \text { to } \\
91.00 \text { (mean: } 78.15 \text { ) } \mathrm{ng} / \mathrm{m}^{3} \text {, respectively }\end{array}$ \\
\hline & Dusts & $\begin{array}{l}\text { E-waste recycling workshops, local residential homes, } \\
\text { exterior street surfaces and control homes, collected } \\
\text { in a mega e-waste recycling industrial park in South } \\
\text { China, between } 2016 \text { and } 2017\end{array}$ & $\begin{array}{l}\text { 246-19,900 (mean: 5600) } \mu \mathrm{g} / \mathrm{g}, 34.5-2030 \\
\quad \text { (mean: 580) } \mu \mathrm{g} / \mathrm{g}, 32.4-982(\text { mean: } 501) \mu \mathrm{g} / \mathrm{g} \\
\text { and } 27.8-173 \text { (mean: 59) } \mu \mathrm{g} / \mathrm{g} \text {, respectively }\end{array}$ \\
\hline & Indoor particles & The Pearl River Delta, China, 2017 & 3.3 to 43.2 (mean: 13.4$) \mathrm{ng} / \mathrm{m}^{3}$ \\
\hline & Indoor particles & Harbin, China, in 2013 & 10.1 to 173.0 (mean: 53.6$) \mu \mathrm{g} / \mathrm{g}$ \\
\hline & Air & $\begin{array}{l}\text { Inside and outside one CP production plant in } \\
\text { Shandong Province, China, } 2016\end{array}$ & $\begin{array}{l}129-1442 \mathrm{ng} / \mathrm{m}^{3} \text { and } 91-333 \mathrm{ng} / \mathrm{m}^{3} \text {, } \\
\text { respectively }\end{array}$ \\
\hline & PM2.5 samples & Jinan, China, 2016 & 9.80 to 105 (mean: 38.7$) \mathrm{ng} / \mathrm{m}^{3}$ \\
\hline & Air & $\begin{array}{l}\text { Shergyla Mountain and Lhasa on the Tibetan Plateau } \\
\text { of China, between } 2012 \text { and } 2015\end{array}$ & $\begin{array}{l}130 \text { and } 1300 \mathrm{pg} / \mathrm{m}^{3} \text { and } 1100-14,440 \mathrm{pg} / \mathrm{m}^{3} \text {, } \\
\text { respectively }\end{array}$ \\
\hline & Household air & Norway, 2012 & 94 to 151 (mean: 128$) \mathrm{ng} / \mathrm{m}^{3}$ \\
\hline & House dust & Canada, between 2007 and 2010 & 4.0-57 (mean: 6.2) $\mu \mathrm{g} / \mathrm{g}$ \\
\hline & Household dusts & Bavaria, Germany & $4-27 \mu \mathrm{g} / \mathrm{g}$ \\
\hline & Indoor dusts & Australia, 2015 & 0.29 to 58 (mean: 9.4$) \mu \mathrm{g} / \mathrm{g}$ \\
\hline & Air & Zurich, Switzerland, 2011 and 2013 & $\begin{array}{l}1.8 \text { to } 17 \text { (median: } 4.3 \text { ) } \mathrm{ng} / \mathrm{m}^{3} \text { and } 1.1 \text { to } \\
42 \mathrm{ng} / \mathrm{m}^{3} \text { (median: } 4.7 \text { ), respectively }\end{array}$ \\
\hline & Air & Japan, South Korea and China, 2008 & $2.26,2.06$ and $137 \mathrm{ng} / \mathrm{m}^{3}$, respectively \\
\hline & Atmosphere & Melbourne, Australia, 2013-14 & $28.4 \mathrm{ng} / \mathrm{m}^{3}$ in summer to $1.8 \mathrm{ng} / \mathrm{m}^{3}$ in winter \\
\hline & Atmosphere & Antarctica, 2012 & 9.6 to 20.8 (mean: $14.9 \mathrm{pg} / \mathrm{m}^{3}$ ) \\
\hline \multirow{5}{*}{$\begin{array}{l}\text { Aquatic } \\
\text { system }\end{array}$} & River water & Shanghai, China, 2016 & $0.278 \mu \mathrm{g} / \mathrm{L}$ \\
\hline & $\begin{array}{l}\text { Influents of wastewater } \\
\text { treatment plants }\end{array}$ & Barcelona, Spain, 2014 & $0.5 \mu \mathrm{g} / \mathrm{L}$ \\
\hline & Surface sediments & East China Sea, 2012 & 5.8 to 64.8 (mean: 25.9 ) ng/g dw \\
\hline & $\begin{array}{l}\text { Surface sediments and } \\
\text { bivalves }\end{array}$ & Bohai Sea in China, 2014 & $\begin{array}{l}97.4-1756.7 \mathrm{ng} / \mathrm{g} \mathrm{dw} \text { and } 476.4-3269.5 \mathrm{ng} / \mathrm{g} \\
\mathrm{dw} \text {, respectively }\end{array}$ \\
\hline & Seawater and sediments & The Pearl River Estuary, Southern China & $\begin{array}{l}180 \text { to } 460 \mathrm{ng} / \mathrm{L} \text { and } 180 \text { to } 620 \mathrm{ng} / \mathrm{g} \text { dry weight } \\
\text { (dw), respectively }\end{array}$ \\
\hline \multirow[t]{13}{*}{ Soils } & Paddy field soils & $\begin{array}{l}\text { An e-waste dismantling area and China between } 2008 \\
\text { and } 2010\end{array}$ & 30.4 to 530 (mean: 80.2 ) ng/g dw \\
\hline & Paddy soils & Liaohe River Basin China, 2010 & $61.5-171.1 \mathrm{ng} / \mathrm{g} \mathrm{dw}$ \\
\hline & Soils & $\begin{array}{l}\text { The Pearl River Delta in South China between } 2009 \\
\text { and } 2010\end{array}$ & 1.9 to 236 (mean: 18.3 ) ng/g dw \\
\hline & Urban soils & Shanghai, China, 2011 & <LOD-615 (mean: 39.4) ng/g dw \\
\hline & Suburban soils & Shanghai, China, 2011 & $<\mathrm{LOD}$ to 697 (mean: 18.8) ng/g dw \\
\hline & Soils & One background area in Shanghai, China, 2011 & 0.42 to 420 (mean: 9.6 ) $\mathrm{ng} / \mathrm{g} \mathrm{dw}$ \\
\hline & $\begin{array}{l}\text { In-plant and ambient surface } \\
\text { soils }\end{array}$ & $\begin{array}{l}\text { A Chinese CP production plant Dalian, China, } \\
\text { between } 2013 \text { and } 2014\end{array}$ & 1421.4 and $141.9 \mathrm{ng} / \mathrm{g} \mathrm{dw}$, respectively \\
\hline & Surface soils & Nationwide agricultural lands China, 2016 & 39 to $1609 \mathrm{ng} / \mathrm{g}$ \\
\hline & Soils & Taizhou, China, 2017 & $68.5-2.2105 \mathrm{ng} / \mathrm{g} \mathrm{dw}$ \\
\hline & Coastal soils & Shandong Peninsula, China, 2017 & 50.06-266.3 (mean: 93.97) ng/g dw \\
\hline & Soils & UK and Norway, 2008 & $24 \pm 72 \mathrm{ng} / \mathrm{g}$ soil organic matter \\
\hline & Soils & Switzerland, 1994 and 2014 & 35 vs. $3.0 \mathrm{ng} / \mathrm{g}$, respectively \\
\hline & Soils & Arctic between 2011 and 2012 & $7.1 \pm 0.7 \mathrm{ng} / \mathrm{g} \mathrm{dw}$ \\
\hline
\end{tabular}


Table 4 (continued)

\begin{tabular}{|c|c|c|c|}
\hline Matrices & & Sites and time of sample collection & Concentrations \\
\hline \multirow[t]{9}{*}{ Biota } & Common barbell Barbus & The Rhone River Basin, France, 2009 & 63-1492 (median: 728) ng/g ww \\
\hline & Aquatic animals & Bohai Bay in Northern China, 2014 and 2017 & 86 to 4400 (mean: 940$) \mathrm{ng} / \mathrm{g}$ ww \\
\hline & Fish & Liaodong Bay, North China, 2014 & 376.3 to 8596 (mean: 2131 ) ng/g lw \\
\hline & Fish & $\begin{array}{l}\text { Alpine lakes and the Lhasa River on the Tibetan } \\
\text { Plateau in } 2019\end{array}$ & $26.6 \mathrm{ng} / \mathrm{g} \mathrm{dw}$ \\
\hline & Wildlife species & Greenland between 2012 and 2014 & Median concentrations of $0.18-2.4 \mu \mathrm{g} / \mathrm{g}$ ww \\
\hline & $\begin{array}{l}\text { Fish, seabirds, marine } \\
\text { mammals and terrestrial } \\
\text { birds and mammals }\end{array}$ & Scandinavia between 2006 and 2017 & $26-1500 \mathrm{ng} / \mathrm{g}$ lw \\
\hline & Aquatic species & Aquatic species & 10 to $1300 \mu \mathrm{g} / \mathrm{g} \mathrm{lw}$ \\
\hline & Coniferous plants & $\begin{array}{l}\text { A chlorinated paraffin plant in Dalian, China, between } \\
2013 \text { and } 2014\end{array}$ & $1738.7 \mathrm{ng} / \mathrm{g} \mathrm{dw}$ \\
\hline & Humpback whales & Antarctica & $46 \mathrm{ng} g / \mathrm{g}$ lw \\
\hline \multirow{10}{*}{$\begin{array}{r}\text { Human } \\
\text { diets }\end{array}$} & Cereal legume meat & 19 Chinese provinces in 2010 & 343 and $328 \mathrm{ng} / \mathrm{g}$ ww, respectively \\
\hline & Aquatic foods & 18 Chinese provinces in 2011 & 215 to 4200 (mean: 1472$) \mathrm{ng} / \mathrm{g}$ ww \\
\hline & Home-produced eggs & An e-waste site in South China, 2013 and 2016 & 477 to $111,000 \mathrm{ng} / \mathrm{g} \mathrm{lw}$ \\
\hline & Raw food materials & Beijing, China, between 2014 and 2016 & 0.67 to $5100 \mathrm{ng} / \mathrm{g} \mathrm{ww}$ \\
\hline & $\begin{array}{l}\text { Diets for the general } \\
\text { population }\end{array}$ & Beijing, China, 2016 & $24.6-546$ (mean: 83 ) ng/g dw \\
\hline & $\begin{array}{l}\text { Mrigal carp, white amur } \\
\text { bream, yellow catfish, pork, } \\
\text { chicken, duck and chicken } \\
\text { eggs }\end{array}$ & $\begin{array}{l}\text { Qingyuan County, South China, between } 2016 \text { and } \\
2017\end{array}$ & $\begin{array}{l}408,4.57,5.64,49.2,43.4,66.1 \text { and } 4.84 \mu \mathrm{g} / \mathrm{g} \\
\text { lw, respectively }\end{array}$ \\
\hline & Composite food & Beijing, China, 1993 and 2009 & $\begin{array}{l}200 \text { to } 600 \mathrm{pg} / \mathrm{g} \text { and } 8500 \text { to } 28,000 \mathrm{pg} / \mathrm{g} \text {, re- } \\
\text { spectively }\end{array}$ \\
\hline & Composite food & Japan, 1993 and 2009 & $\begin{array}{l}<\mathrm{LOD}-290 \mathrm{pg} / \mathrm{g} \text { ww and }<\mathrm{LOD}-1100 \mathrm{pg} / \mathrm{g} \text { ww, } \\
\text { respectively }\end{array}$ \\
\hline & Chicken eggs & An e-waste recycling region in China, 2013 & 2600-6800 (mean: 4000) ng/g lw \\
\hline & Vitamin E dietary supplements & German market with data not indicated & $<$ LOD to 61,000 (mean: 3810 ) ng/g fat \\
\hline \multirow{8}{*}{$\begin{array}{l}\text { Human } \\
\text { tissues }\end{array}$} & Blood & China in 2012 & 370-35,000 (median: 3500) ng/g lw \\
\hline & Maternal and cord serum & Beijing, China, 2013 & $\begin{array}{l}21.7-373 \mathrm{ng} / \mathrm{g} \text { ww and } 8.51-107 \mathrm{ng} / \mathrm{g} \mathrm{ww}, \\
\text { respectively }\end{array}$ \\
\hline & Plasma & Dalian, China, 2015 & $<$ LOD to 203 (mean: 32) ng/g ww \\
\hline & Human milk & $\begin{array}{l}\text { Eight Chinese provinces, } 2007 \text { and from } 16 \text { Chinese } \\
\text { provinces, } 2011\end{array}$ & 303 and $360 \mathrm{ng} / \mathrm{g}$ lw \\
\hline & Human milk & 12 Chinese provinces in 2007 and 16 provinces, 2011 & 681 and $733 \mathrm{ng} / \mathrm{g}$ lw, respectively \\
\hline & Human milk & China between 2014 and 2015 & $2.51 \mu \mathrm{g} / \mathrm{g}$ lw \\
\hline & Human milk & UK between 2001 and 2002 & $0.18 \mu \mathrm{g} / \mathrm{g}$ lw \\
\hline & Placenta & China, 2018 & $98.5-3771 \mathrm{ng} / \mathrm{lw}$ \\
\hline
\end{tabular}

Data were compiled from a table by Wang et al. (2019b)

ranging from 1.00 to $5.45 \mathrm{ng} \mathrm{mL}^{-1}$ were determined by Zhou et al. (2019), which were lower than those obtained in plasma (Li et al. 2017b) and human blood (Xu et al. 2019c). In Australia, a study done by van Mourik et al. (2020a) showed SCCP concentration in human male serum samples which ranged from $<\mathrm{MDL}$ to 0.68 with $\sum \mathrm{SCCPs}$ of $0.54 \mathrm{ng} \mathrm{g}^{-1}$ ww. The concentrations obtained were lower than those obtained in human, maternal and cord serum samples from China (Zhou et al. 2019; Qiao et al. 2018). In addition to the SCCP studies reviewed above, Table 4 summarizes SCCP studies in different matrices from different continents.

\section{Research gap and priorities on SCCP studies in Africa}

Africa is the second largest continent in the world covering over 30 million $\mathrm{km}^{2}$, including over 54 countries and a population of about 1.17 billion people (UNDP 2015). Apart from the three SCCP studies conducted in Africa (Adu-Kumi-Jonathan et al. 2019, Brits et al. 2020, Möckel et al. 2020), it remains the least studied continent in the world with respect to SCCP studies in different matrices. However, about 199 CP studies have been published in other continents in matrices such as river, sediments, 
soil, fish, human blood and serum, consumer products and landfill sites, which reveals that there remains a huge research gap in the continent of Africa. Studies have further indicated that the analysis of SCCPs is a challenging and demanding task due to the complexity of their industrial mixtures and interferences with other organic compounds; therefore, only a few laboratories are involved in their quantification (van Mourik et al. 2015; Schinkel et al. 2018). Considering that Africa is a developing continent, factors such as lack of technical support may be some of the reasons behind the limited conducted studies on SCCPs. Currently, there are no published reports on SCCP concentration in consumer products, landfill leachate and sediment samples in Africa. Furthermore, though the production and use of SCCPs have been prohibited in some countries including the US, Japan and Brazil because of their toxicity and effects in the environment, there are no immediate actions or regulations on the production and use of SCCPs in Africa. The current climate change, which is being felt across Africa and the rest of the world, will exacerbate the situation if no measures are taken to ameliorate the situation. Furthermore, information about environmental levels of SCCPs in Africa is essential for guiding efforts to reduce health implications associated with the contaminant in order to achieve the United Nations' Sustainable Development Goals (SDGs) on healthy lives and the promotion of well-being for all at all ages by 2030. There is, therefore, a critical need to study environmental concentrations of SCCPs in Africa as well as to expand sampling sites to include landfill leachates, consumer goods and other matrices. Historical sources, current sources and Africa's characteristics make Africa an important study area. In addition, Africa needs to assess the presence, use and life cycle of SCCPs in the continent and develop a National Implementation Plan with specific activities. Moreover, there is a need of developing SCCP inventories of which the Stockholm Convention has already developed a guidance document in this respect (UNEP 2019a).

\section{Concluding remarks}

In comparing SCCP studies done in Africa so far with those published in other continents, it is clear that there remains a huge gap in CP studies. There are limited published studies on the determination of SCCP concentration in consumer products and landfills as well as in other different matrices in the continent, and as such, further research studies are necessary in order to tackle those research gaps. Additionally, very few studies have so far reported on SCCP concentration in landfill leachate and sediment globally. Nearly all imports of CPs and CP-containing waste end up in dump sites or landfills in Africa. The lack of resources on intensive analytical methods and elaborate sampling techniques required may be the reason for fewer SCCP studies in Africa; therefore, attention should be given to this area. Temperature is one of the key meteorological parameters that can severely influence the global distribution of SCCPs in the environment. Due to the hot climate experienced in Africa, SCCPs can be evaporated and thereby influence the reemission and distribution of SCCPs to other regions. In view of the effects of SCCPs globally, the use of SCCPs needs to be legally restricted/banned and not used in many exempted applications as prescribed by the Stockholm Convention. Robust SCCP inventories and other CPs containing SCCPs are overdue in Africa and, therefore, require some attentions. It is, therefore, important to gather comparable data on concentrations of SCCPs in consumer products and other matrices in all the continents in order to have a global overview of the state SCCPs. It is also crucial to study SCCPs in Africa in order to understand the impacts of the Stockholm Convention to reduce POPs in Africa and to assess their distribution and influence of other continents to the environmental burden of SCCPs in Africa, and vice versa.

Acknowledgements The authors are very grateful to the Tshwane University of Technology (TUT) and the National Research Foundation (NRF) for the grants provided for this research.

Author contribution Miss VN Nevondo prepared the draft manuscript, while Prof OJ Okonkwo edited and proofread the manuscript before submission for consideration for publication. All authors read and approved the final manuscript.

Funding This study was funded by the Tshwane University of Technology (TUT) and the National Research Foundation (NRF)

Data availability Not applicable

\section{Declarations}

Ethics approval and consent to participate Not applicable

Competing interests The authors declare no competing interests.

Open Access This article is licensed under a Creative Commons Attribution 4.0 International License, which permits use, sharing, adaptation, distribution and reproduction in any medium or format, as long as you give appropriate credit to the original author(s) and the source, provide a link to the Creative Commons licence, and indicate if changes were made. The images or other third party material in this article are included in the article's Creative Commons licence, unless indicated otherwise in a credit line to the material. If material is not included in the article's Creative Commons licence and your intended use is not permitted by statutory regulation or exceeds the permitted use, you will need to obtain permission directly from the copyright holder. To view a copy of this licence, visit http://creativecommons.org/licenses/by/4.0/.

\section{References}

Aamir M, Yin S, Guo F, Liu K, Xu C, Liu W (2019) Congener-specific mother-fetus distribution, placental retention, and transport of $\mathrm{C} 10$ 
13 and $\mathrm{C} 14-17$ chlorinated paraffins in pregnant women. Environ Sci Technol 53:11458-11466. https://doi.org/10.1021/acs.est. $9 \mathrm{~b} 02116$

Adu-Kumi-Jonathan JP, Akortia HE, Bell GK, Di Gangi J (2019) Persistent organic pollutants (POPs) in eggs: report from Africa.

Asante KA, Adu-Kumi S, Nakahiro K, Takahashi S, Isobe T, Sudaryanto A, Devanathan G, Clarke E, Ansa-Asare OD, Dapaah-Siakwan S (2011) Tanabe S (2011) Human exposure to PCBs, PBDEs and HBCDs in Ghana: temporal variation, sources of exposure and estimation of daily intakes by infants. Environ Int 37:921-928. https:// doi.org/10.1016/j.envint.2011.03.011

Babayemi JO, Sindiku O, Osibanjo O, Weber R (2014) Substance flow analysis of polybrominated diphenyl ethers in plastic from WEEE/ EEE in Nigeria as a basis for policy advice. Environ Sci Pollut Res Int 22:14502-14514. https://doi.org/10.1007/s11356-014-3228-6

Babayemi J, Sindiku O, Osibanjo O, Weber R (2015) Substance flow analysis of polybrominated diphenyl ethers in plastic from EEE/ WEEE in Nigeria in the frame of Stockholm Convention as a basis for policy advice. Environ Sci Pollut Res 22:14502-14514. https:// doi.org/10.1007/s11356-014-3228-6

Babayemi JO, Osibanjo O, Sindiku O, Weber R (2018) Inventory and substance flow analysis of polybrominated diphenyl ethers in the Nigerian transport sector-end-of-life vehicles policy and management. Environ Sci Pollut Res 25:31805-31818. https://doi.org/10. 1007/s11356-016-6574-8

Babayemi JO, Nnorom IC, Osibanjo O, Weber R (2019) Ensuring sustainability in plastics use in Africa: consumption, waste generation, and projections. Environ Sci Eur 31:1-20. https://doi.org/10.1186/ s12302-019-0254-5

Barber JL, Sweetman AJ, Thomas GO, Braekevelt E, Stern GA, Jones KC (2005) Spatial and temporal variability in air concentrations of short-chain $(\mathrm{C} 10-\mathrm{C} 13)$ and medium-chain $(\mathrm{C} 14-\mathrm{C} 17)$ chlorinated n-alkanes measured in the UK atmosphere. Environ Sci Technol 39: 4407-4415. https://doi.org/10.1021/es047949w

Basconcillo LS, Backus SM, McGoldrick DJ, Zaruk D, Sverko E, Muir DC (2015) Current status of short-and medium chain polychlorinated n-alkanes in top predatory fish across Canada. Chemosphere 127:93-100. https://doi.org/10.1016/j.chemosphere. 2015.01.016

Bayen S, Obbard JP, Thomas GO (2006) Chlorinated paraffins: a review of analysis and environmental occurrence. Environ Int 32:915-929. https://doi.org/10.1016/j.aca.2015.11.009

Bidleman TF, Helm PA, Braune BM, Gabrielsen GW (2010) Polychlorinated naphthalenes in polar environments - a review. Sci Total Environ 408:2919-2935. https://doi.org/10.1016/j. scitotenv.2009.09.013

Bogdal C, Niggeler N, Glüge J, Diefenbacher PS, Wächter D, Hungerbühler K (2017) Temporal trends of chlorinated paraffins and polychlorinated biphenyls in Swiss soils. Environ Pollut 220: 891-899. https://doi.org/10.1016/j.envpol.2016.10.073

Boreen AR, Schlabach M, Mariussen E (2003) Screening of chlorinated paraffins in Norway. Organohalogen Compd 60:331-334

Borgen AR, Schlabach M, Kallenborn R, Christensen G, Skotvold T (2002) Polychlorinated alkanes in ambient air from Bear Island. Organohalogen Compd 59:303-306

Brandsma SH, van Mourik L, O'Brien JW, Eaglesham G, Leonards PE, De Boer J, Gallen C, Mueller J, Gaus C, Bogdal C (2017) Mediumchain chlorinated paraffins (CPs) dominate in Australian sewage sludge. Environ Sci Technol 51:3364-3372. https://doi.org/10. 1021/acs.est.6b05318

Brandsma SH, Brits M, Groenewoud QR, van Velzen MJ, Leonards PE, De Boer J (2019) Chlorinated paraffins in car tires recycled to rubber granulates and playground tiles. Environ Sci Technol 53:75957603. https://doi.org/10.1021/acs.est.9b01835

Brits M, De Boer J, Rohwer ER, De Vos J, Weiss JM, Brandsma SH (2020) Short-, medium-, and long-chain chlorinated paraffins in
South African indoor dust and cat hair. Chemosphere 38:12464. https://doi.org/10.1016/j.chemosphere.2019.124643

Campbell B (2009) Mining in Africa: regulation and development. Pluto Press, IDRC

Cao Y, Harada KH, Hitomi T, Niisoe T, Wang P, Shi Y, Yang HR, Takasuga T, Koizumi A (2017) Lactational exposure to shortchain chlorinated paraffins in China, Korea, and Japan. Chemosphere 173:43-48. https://doi.org/10.1016/j.chemosphere. 2016.12.078

Castells P, Parera J, Santos FJ, Galceran MT (2008) Occurrence of polychlorinated naphthalenes, polychlorinated biphenyls and short-chain chlorinated paraffins in marine sediments from Barcelona (Spain). Chemosphere 70:1552. https://doi.org/10.1016/ j.chemosphere.2007.08.034

Chaemfa C, Xu Y, Li J, Chakraborty P, Hussain Syed J, Naseem Malik R, Wang Y, Tian C, Zhang G, Jones KC (2014) Screening of atmospheric short-and medium-chain chlorinated paraffins in India and Pakistan using polyurethane foam based passive air sampler. Environ Sci Technol 48:4799-4808. https://doi.org/10.1021/ es $405186 \mathrm{~m}$

Chang CY, Chung WH, Ding WH (2016) Vortex-assisted liquid-liquid microextraction for the rapid screening of short-chain chlorinated paraffins in water. J Sep Sci 39:42732. https://doi.org/10.1002/ jssc. 201500991

Chen MY, Luo XJ, Zhang XL, He MJ, Chen SJ, Mai BX (2011) Chlorinated paraffins in sediments from the Pearl River Delta, South China: spatial and temporal distributions and implication for processes. Environ Sci Technol 45:9936-9943. https://doi.org/10. 1021/es202891a

Chen YH, Chang CY, Ding WH (2016) Vortex-homogenized matrix solid-phase dispersion for the extraction of short chain chlorinated paraffins from indoor dust samples. J Chromatogr A 1472:129-133. https://doi.org/10.1016/j.chroma.2016.10.048

Chen H, Lam JC, Zhu M, Wang F, Zhou W, Du B, Zeng L, Zeng EY (2018) Combined effects of dust and dietary exposure of occupational workers and local residents to short-and medium-chain chlorinated paraffins in a mega E-waste recycling industrial park in South China. Environ Sci Technol 52:11510-11519. https://doi. org/10.1021/acs.est.8b02625

Coelhan M (2010) Levels of chlorinated paraffins in water. Clean-Soil, Air, Water 38:452-456

CPIA (Chlorinated Paraffins Industry Association) (2002) Comments on the draft report "Short chain chlorinated paraffins (sPCAs) substance dossier" (Draft March 2), Correspondence to G. Filyk, Environment Canada, from R. Fensterheim, CPIA, 17 May 2002, CPIA, Washington, DC, USA

Darnerud PO, Eriksen GS, Jóhannesson T, Larsen PB, Viluksela M (2001) Polybrominated diphenyl ethers: occurrence, dietary exposure, and toxicology. Environ Health Perspect 109:49-68. https:// doi.org/10.1289/ehp.01109s 149

Diefenbacher PS, Bogdal C, Gerecke AC, Glüge J, Schmid P, Scheringer M, Hungerbühler K (2015) Short-chain chlorinated paraffins in Zurich, Switzerland atmospheric concentrations and emissions. Environ Sci Technol 49:9778-9786. https://doi.org/10.1021/acs. est. 5 b02153

Ding L, Luo N, Liu Y, Fang X, Zhang S, Li S, Jiang W, Zhao N (2020) Short and medium-chain chlorinated paraffins in serum from residents aged from 50 to 84 in Jinan, China: occurrence, composition and association with hematologic parameters. Sci Total Environ 728:137998. https://doi.org/10.1016/j.scitotenv.2020.137998

Dong S, Zhang S, Li X, Li T, Fan M, Wang Y, Cheng J, Wang R, Zou Y, Wang S, Suo D (2020) Short-and medium-chain chlorinated paraffins in plastic animal feed packaging and factors affect their migration into animal feed. J Hazard Mater 389:121836. https://doi.org/ 10.1016/j.jhazmat.2019.121836 
ECB (European Chemicals Bureau) (2007) European Union Risk Assessment Report - Alkanes, C14e17, Chloro. Environmental Addendum of August 2007. European Chemicals Bureau, Joint Research Centre, European Commission. Scientific and Technical Research Reports. http://esis.jrc.ec.europa.eu/doc/risk assessment/ ADDENDUM/mccp_add_331.pdf

EFSA (European Food Safety Authority) (2020) Risk assessment of chlorinated paraffins in feed and food. https://doi.org/10.2903/j.efsa. 2020.5991

Environment Canada (2008) Canadian Environmental Protection Act, 1999. Follow-up report on a PSL1 assessment for which data were insufficient to conclude whether the substances were "toxic" to the environment and to the human health: chlorinated paraffins. http:// www.ec.gc.ca/lcpe-cepa/documents/substances/pc-cp/cps followup-eng.pdf

ESWI (European Scientific Working group on Influenza) (2011) Study on waste related issues of newly listed POPs and candidate POPs. Consortium ESWI (Bipro, Umweltbundesamt and Enviroplan) for the European Commission

European Commission (2010) European Commission Directive 2010/75/ EU of the European Parliament and of the Council of 24 November 2010 on Industrial Emissions (Integrated Pollution Prevention and Control)

Feo ML, Eljarrat E, Barcelo D (2009) Occurrence, fate and analysis of polychlorinated n-alkanes in the environment. TrAC Trends Anal Chem 28:778-791. https://doi.org/10.1016/j.trac.2009.04.009

Fiedler H (2010) Short-chain chlorinated paraffins: production, use and international regulations. In: Boer J (ed) Chlorinated paraffins 2010, The handbook of environmental chemistry, vol 10. Springer, Berlin, pp 1-40. https://doi.org/10.1007/698_2010_58

Fridén UE (2010) Sources, emissions, and occurrence of chlorinated paraffins in Stockholm, Sweden. Dissertation, Stockholm University.

Fridén UE, McLachlan MS, Berger U (2011) Chlorinated paraffins in indoor air and dust: concentrations, congener patterns, and human exposure. Environ Int 37:1169-1174. https://doi.org/10.1016/j. envint.2011.04.002

Gallistl C, Lok B, Schlienz A, Vetter W (2017) Polyhalogenated compounds (chlorinated paraffins, novel and classic flame retardants, POPs) in dishcloths after their regular use in households. Sci Total Environ 595:303-314. https://doi.org/10.1016/j.scitotenv.2017.03. 217

Gallistl C, Sprengel J, Vetter W (2018) High levels of medium-chain chlorinated paraffins and polybrominated diphenyl ethers on the inside of several household baking oven doors. Sci Total Environ 615:1019-1027. https://doi.org/10.1016/j.scitotenv.2017.09.112

Gandolfi F, Malleret L, Sergent M, Doumenq P (2015) Parameters optimization using experimental design for headspace solid phase micro-extraction analysis of short-chain chlorinated paraffins in waters under the European water framework directive. J Chromatogr A 1406:59-67. https://doi.org/10.1016/j.chroma.2015.06.030

Gao Y, Zhang H, Su F, Tian Y, Chen J (2012) Environmental occurrence and distribution of short chain chlorinated paraffins in sediments and soils from the Liaohe River Basin, PR China. Environ Sci Technol 46:3771-3778. https://doi.org/10.1021/es2041256

Gao W, Cao D, Wang Y, Wu J, Wang Y, Wang Y, Jiang G (2018) External exposure to short-and medium-chain chlorinated paraffins for the general population in Beijing, China. Environ Sci Technol 52:32-39. https://doi.org/10.1021/acs.est.7b04657

Geyer R, Jambeck JR, Law KL (2017) Production, use, and fate of all plastics ever made. Sci Adv 3:1700782. https://doi.org/10.1126/ sciadv. 1700782

GIA (Global Industry Analysis) (2008) Plastic additives: a global strategic business report (MCP-2122, GIA) https://www.strategyr.com/ Plastic_Additives_Market_Report.asp

Gioia R, Akindele AJ, Adebusoye SA, Asante KA, Tanabe S, Buekens A, Sasco AJ (2014) Polychlorinated biphenyls (PCBs) in Africa: a review of environmental levels. Environ Sci Pollut Res 21:62786289. https://doi.org/10.1007/s11356-013-1739-1

Glüge J, Wang Z, Bogdal C, Scheringer M, Hungerbühler K (2016) Global production, use, and emission volumes of short-chain chlorinated paraffins-a minimum scenario. Sci Total Environ 573:11321146. https://doi.org/10.1016/j.scitotenv.2016.08.105

Gong Y, Zhang H, Geng N, Xing L, Fan J, Luo Y, Song X, Ren X, Wang F, Chen J (2018) Short-chain chlorinated paraffins (SCCPs) induced thyroid disruption by enhancement of hepatic thyroid hormone influx and degradation in male Sprague Dawley rats. Sci Total Environ 625:657-666. https://doi.org/10.1016/j.scitotenv.2017.12. 251

Guida Y, Capella R, Weber R (2020) Chlorinated paraffins in the technosphere: a review of available information and data gaps demonstrating the need to support the Stockholm Convention implementation. Emerg Contam 6:143-154. https://doi.org/10.1016/j.emcon. 2020.03.003

Hahladakis JN, Velis CA, Weber R, Iacovidou E, Purnell P (2018) An overview of chemical additives present in plastics: migration, release, fate and environmental impact during their use, disposal and recycling. J Hazard Mater 344:179-199. https://doi.org/10.1016/j. jhazmat.2017.10.014

Halse AK, Schlabach M, Schuster JK, Jones KC, Steinnes E, Breivik K (2015) Endosulfan, pentachlorobenzene and short-chain chlorinated paraffins in background soils from Western Europe. Environ Pollut 196:21-28. https://doi.org/10.1016/j.envpol.2014.09.009

He C, Brandsma SH, Jiang H, O'Brien JW, van Mourik LM, Banks AP, Wang X, Thai PK, Mueller JF (2019) Chlorinated paraffins in indoor dust from Australia: levels, congener patterns and preliminary assessment of human exposure. Sci Total Environ 682:318-323. https://doi.org/10.1016/j.scitotenv.2019.05.170

Herzke D, Kaasa H, Harju M (2013) Perfluorinated alkylated substances (PFAS), brominated flame retardants (BFR) and chlorinated paraffins (CP) in the Norwegian Environment Screening 2013. NILU $\mathrm{OR}$.

Hilger B, Fromme H, Völkel W, Coelhan M (2013) Occurrence of chlorinated paraffins in house dust samples from Bavaria, Germany. Environ Pollut 175:16-21. https://doi.org/10.1016/j.envpol.2012. 12.011

Houde M, Muir DC, Tomy GT, Whittle DM, Teixeira C, Moore S (2008) Bioaccumulation and trophic magnification of short-and mediumchain chlorinated paraffins in food webs from Lake Ontario and Lake Michigan. Environ Sci Technol 42:3893-3899. https://doi. org/10.1021/es703184s

Howard PH, Santodonato J, Saxena SJ (1975) Investigation of selected potential environmental contaminants, chlorinated paraffins. United States

Huang H, Gao L, Xia D, Qiao L, Wang R, Su G, Liu W, Liu G, Zheng M (2017) Characterization of short-and medium-chain chlorinated paraffins in outdoor/indoor PM10/PM2. 5/PM1. 0 in Beijing, China. Environ Pollut 225:674-680. https://doi.org/10.1016/j.envpol.2017. 03.054

Huang Y, Chen L, Jiang G, He Q, Ren L, Gao B, Cai L (. (2019a) Bioaccumulation and biomagnification of short-chain chlorinated paraffins in marine organisms from the Pearl River Estuary, South China. Sci Total Environ 671:262-269. https://doi.org/10.1016/j. scitotenv.2019.03.346

Huang Y, Qing X, Jiang G, Chen L, He Q, Meng XZ, Gao B (2019b) Short-chain chlorinated paraffins in fish from two developed regions of China: occurrence, influencing factors and implication for human exposure via consumption. Chemosphere 236:124317. https://doi. org/10.1016/j.chemosphere.2019.07.048

Huang D, Gao L, Qiao L, Cui L, Xu C, Wang K, Zheng M (2020) Concentrations of and risks posed by short-chain and mediumchain chlorinated paraffins in soil at a chemical industrial park on 
the southeast coast of China. Environ Pollut 258:113704. https://doi. org/10.1016/j.envpol.2019.113704

IARC (International Agency for Research on Cancer) (1990) Chlorinated paraffins of average carbon chain length $\mathrm{C} 12$ and average degree of chlorination approximately 60. IARC Monogr Eval Carcinog Risks Hum 48:55-72

ICIS (Independent Commodity Intelligence Services) (1995) Who's who in South Africa http://www.icis.com/resources/news/1995/05/29/ 18436/who-s-who-in-south-africa/

Iozza S, Müller CE, Schmid P, Bogdal C, Oehme M (2008) Historical profiles of chlorinated paraffins and polychlorinated biphenyls in a dated sediment core from Lake Thun (Switzerland). Environ Sci Technol 42:1045-1050. https://doi.org/10.1021/es702383t

Kalinowska K, Lenartowicz P, Namieśnik J, Marć M (2019) Analytical procedures for short chain chlorinated paraffins determination-How to make them greener? Sci Total Environ 671:309-323. https://doi. org/10.1016/j.scitotenv.2019.03.312

Katima Z, Okonkwo JO, Daso AP (2017) A review of brominated flame retardants in the environment with emphasis on atmospheric levels, knowledge and information gaps in the African continent. Atmos Pollut Res 2018:767-780. https://doi.org/10.1016/j.apr.2016.12. 017

Labadie P, Blasi C, Le Menach K, Geneste E, Babut M, Perceval O, Budzinski H (2019) Evidence for the widespread occurrence of short-and medium-chain chlorinated paraffins in fish collected from the Rhône River basin (France). Chemosphere 223:232-239. https:// doi.org/10.1016/j.chemosphere.2019.02.069

Lassen C, Sørensen G, Crookes M, Christensen F, Jeppesen CN, Warming M, Mikkelsen SH, Nielsen JM (2014) Survey of shortchain and medium-chain chlorinated paraffins. Report for the Danish Ministry of the Environment

Li Q, Li J, Wang Y, Xu Y, Pan X, Zhang G, Luo C, Kobara Y, Nam JJ, Jones KC (2012) Atmospheric short-chain chlorinated paraffins in China, Japan, and South Korea. Environ Sci Technol 46:1194811954. https://doi.org/10.1021/es302321n

Li H, Fu J, Pan W, Wang P, Li Y, Zhang Q, Wang Y, Zhang A, Liang Y, Jiang G (2017a) Environmental behaviour of short-chain chlorinated paraffins in aquatic and terrestrial ecosystems of Ny-Ålesund and London Island, Svalbard, in the Arctic. Sci Total Environ 590:163170. https://doi.org/10.1016/j.scitotenv.2017.02.192

Li T, Wan Y, Gao S, Wang B, Hu J (2017b) High-throughput determination and characterization of short-, medium-, and long-chain chlorinated paraffins in human blood. Environ Sci Technol 51:33463354. https://doi.org/10.1021/acs.est.6b05149

Li T, Gao S, Ben Y, Zhang H, Kang Q, Wan Y (2018) Screening of chlorinated paraffins and unsaturated analogues in commercial mixtures: confirmation of their occurrences in the atmosphere. Environ Sci Technol 52:1862-1870. https://doi.org/10.1021/acs.est. $7 \mathrm{~b} 04761$

Li H, Bu D, Gao Y, Zhu N, Wu J, Chen X, Fu J, Wang Y, Zhang A, Jiang $G$ (2019) Long-range atmospheric transport and alpine condensation of short-chain chlorinated paraffins on the southeastern Tibetan Plateau. J Environ Sci 99:275-280. https://doi.org/10.1016/j.jes. 2020.06 .023

Li J, Xu L, Zhou Y, Yin G, Wu Y, Yuan GL, Du X (2020) Short-chain chlorinated paraffins in soils indicate landfills as local sources in the Tibetan Plateau. Chemosphere 263:128341. https://doi.org/10.1016/ j.chemosphere.2020.128341

Liu LH, Ma WL, Liu LY, Huo CY, Li WL, Gao CJ, Li HL, Li YF, Chan HM (2017) Occurrence, sources and human exposure assessment of SCCPs in indoor dust of northeast China. Environ Pollut 225:232243. https://doi.org/10.1016/j.envpol.2017.03.008

Liu D, Li Q, Cheng Z, Li K, Li J, Zhang G (2020a) Spatiotemporal variations of chlorinated paraffins in PM2. 5 from Chinese cities: implication of the shifting and upgrading of its industries. Environ Pollut 259:113853. https://doi.org/10.1016/j.envpol.2019.113853
Liu Y, Aamir M, Li M, Liu K, Hu Y, Liu N, Xu Y, Du J, Xu J, Liu W (2020b) Prenatal and postnatal exposure risk assessment of chlorinated paraffins in mothers and neonates: occurrence, congener profile, and transfer behavior. J Hazard Mater 13:122660. https://doi. org/10.1016/j.jhazmat.2020.122660

Lucattini L, Poma G, Covaci A, de Boer J, Lamoree MH, Leonards PE (2018) A review of semi-volatile organic compounds (SVOCs) in the indoor environment: occurrence in consumer products, indoor air and dust. Chemosphere 201:466-482. https://doi.org/10.1016/j. chemosphere.2018.02.161

Lyche JL, Rosseland C, Berge G, Polder A (2015) Human health risk associated with brominated flame-retardants (BFRs). Environ Int 74:170-180. https://doi.org/10.1016/j.envint.2014.09.006

Ma X, Chen C, Zhang H, Gao Y, Wang Z, Yao Z, Chen J, Chen J (2014a) Congener-specific distribution and bioaccumulation of short-chain chlorinated paraffins in sediments and bivalves of the Bohai Sea, China. Mar Pollut Bull 79:299-304. https://doi.org/10.1016/j. marpolbul.2013.11.020

Ma X, Zhang H, Wang Z, Yao Z, Chen J, Chen J (2014b) Bioaccumulation and trophic transfer of short chain chlorinated paraffins in a marine food web from Liaodong Bay, North China. Environ Sci Technol 48:5964-5971. https://doi.org/10.1021/ es500940p

Mansour SA (2009) Persistent organic pollutants (POPs) in Africa: Egyptian scenario. Hum Exp Toxicol 28:531-566. https://doi.org/ 10.1177/0960327109347048

Martínez Prats R (2015) Determination of short-chain chlorinated paraffins in gull egg samples by gas chromatography-mass spectrometry. Available from: TFG_QU_Martinez Prats Raimon.pdf

Möckel C, Breivik K, Nøst TH, Sankoh A, Jones KC, Sweetman A (2020) Soil pollution at a major West African E-waste recycling site: contamination pathways and implications for potential mitigation strategies. Environ Int 137:105563. https://doi.org/10.1016/j. envint.2020.105563

Morales L, Martrat MG, Olmos J, Parera J, Vicente J, Bertolero A, Ábalos M, Lacorte S, Santos FJ, Abad E (2012) Persistent organic pollutants in gull eggs of two species (Larus michahellis and Larus audouinii) from the Ebro delta Natural Park. Chemosphere 88: 1306-1316. https://doi.org/10.1016/j.chemosphere.2012.03.106

Muscalu AM, Morse D, Reiner EJ, Górecki T (2017) The quantification of short-chain chlorinated paraffins in sediment samples using comprehensive two-dimensional gas chromatography with $\mu \mathrm{ECD}$ detection. Anal Bioanal Chem 409:2065-2074. https://doi.org/10.1007/ s00216-016-0153-1

Nicholls CR, Allchin CR, Law RJ (2001) Levels of short and medium chain length polychlorinated $n$-alkanes in environmental samples from selected industrial areas in England and Wales. Environ Pollut 114:415-430. https://doi.org/10.1016/S0269-7491(00) 00230-X

Niu S, Chen R, Zou Y, Dong L, Hai R, Huang Y (2020) Spatial distribution and profile of atmospheric short-chain chlorinated paraffins in the Yangtze River Delta. Environ Pollut 259:113958. https://doi. org/10.1016/j.envpol.2020.113958

Nkabinde SN, Okonkwo JO, Olukunle OI, Daso AP (2018) Determination of legacy and novel brominated flame-retardants in dust from end of life office equipment and furniture from Pretoria, South Africa. Sci Total Environ 622:275-281. https://doi.org/10. 1016/j.scitotenv.2017.11.294

Odusanya DO, Okonkwo JO, Botha B (2009) Polybrominated diphenyl ethers (PBDEs) in leachates from selected landfill sites in South Africa. Waste Manag 1:96-102. https://doi.org/10.1016/j.wasman. 2008.02.011

Oloruntoba K, Sindiku O, Osibanjo O, Balan S, Weber R (2019) Polybrominated diphenyl ethers (PBDEs) in chicken eggs and cow milk around municipal dumpsites in Abuja, Nigeria. Ecotoxicol 
Environ Saf 179:282-289. https://doi.org/10.1016/j.ecoenv.2019. 04.045

Pan X, Tang J, Chen Y, Li J, Zhang G (2011a) Polychlorinated naphthalenes (PCNs) in riverine and marine sediments of the Laizhou Bay area, North China. Environ Pollut 159:3515-3521. https://doi.org/ 10.1016/j.envpol.2011.08.016

Pan X, Tang J, Li J, Zhong G, Chen Y, Zhang G (2011b) Polybrominated diphenyl ethers (PBDEs) in the riverine and marine sediments of the Laizhou Bay area, North China. J Environ Monit 13:886-893. https://doi.org/10.1039/C1EM10169B

Pan X, Tang J, Tian C, Li J, Zhang G (2018) Short-and medium-chain chlorinated paraffins in sediments from the Laizhou Bay area, North China: implications for transportation from rivers to marine environment. Environ Pollut 243:1460-1468. https://doi.org/10.1016/j. envpol.2018.09.123

Pan X, Zhen X, Tian C, Tang J (2020) Distributions, transports and fates of short-and medium-chain chlorinated paraffins in a typical riverestuary system. Sci Total Environ 751:141769-141468. https://doi. org/10.1016/j.envpol.2018.09.123

Parera J, Abalos M, Santos FJ, Galceran MT, Abad E (2013) Polychlorinated dibenzo-p-dioxins, dibenzofurans, biphenyls, paraffins and polybrominated diphenyl ethers in marine fish species from Ebro River Delta (Spain). Chemosphere 93:499-505. https://doi. org/10.1016/j.chemosphere.2013.06.022

PDEP (Pennsylvania Department of Environmental Protection) (2019) Halogens and Waste Oil. Fact Sheet

Pellizzato F, Ricci M, Held A, Emons H, Böhmer W, Geiss S, Iozza S, Mais S, Petersen M, Lepom P (2009) Laboratory intercomparison study on the analysis of short-chain chlorinated paraffins in an extract of industrial soil. TrAC Trends Anal Chem 28:1029-1035. https://doi.org/10.1016/j.trac.2009.05.002

POPRC (Persistent Organic Pollutant Review Committee) (2015) Shortchained chlorinated paraffins: risk profile document UNEP/POPS/ POPRC.11/10/Add.2. United Nations Environmental Programme Stockholm Convention on Persistent Organic Pollutants, Geneva

POPRC (Persistent Organic Pollutant Review Committee) (2017) Eighth Meeting of the Conference of the Parties to the Stockholm Convention. http://www.pops.int/TheConvention/ ConferenceoftheParties/Meetings/COP8/tabid/5309/Default.aspx

Přibylová P, Klánová J, Holoubek I (2006) Screening of short-and medium-chain chlorinated paraffins in selected riverine sediments and sludge from the Czech Republic. Environ Pollut 144(1):248-254. https://doi.org/10.1016/j.envpol.2005.12.020

Qiao L, Xia D, Gao L, Huang H, Zheng M (2016) Occurrences, sources and risk assessment of short-and medium-chain chlorinated paraffins in sediments from the middle reaches of the Yellow River, China. Environ Pollut 219:483-489. https://doi.org/10.1016/j. envpol.2016.05.057

Qiao L, Gao L, Xia D, Huang H, Zheng M (2017) Short-and mediumchain chlorinated paraffins in sediments from the middle reaches of the Yangtze River: spatial distributions, source apportionment and risk assessment. Sci Total Environ 575:1177-1182. https://doi.org/ 10.1016/j.scitotenv.2016.09.193

Qiao L, Gao L, Zheng M, Xia D, Li J, Zhang L, Wu Y, Wang R, Cui L, $\mathrm{Xu} C$ (2018) Mass fractions, congener group patterns, and placental transfer of short-and medium-chain chlorinated paraffins in paired maternal and cord serum. Environ Sci Technol 52:10097-10103. https://doi.org/10.1021/acs.est.8b02839

Rajaram S (2009) Plastic additives: the global market. PLS022B, BCC Research. https://www.bccresearch.com/market-research/plastics/ plastic-additives-market-pls022b.html

Ren X, Zhang H, Geng N, Xing L, Zhao Y, Wang F, Chen J (2018) Developmental and metabolic responses of zebrafish (Danio rerio) embryos and larvae to short-chain chlorinated paraffins (SCCPs) exposure. Sci Total Environ 2018 622:214-21.https://doi.org/10. 1016/j.scitotenv.2017.11.304
Reth M, Oehme M (2004) Limitations of low resolution mass spectrometry in the electron capture negative ionization mode for the analysis of short-and medium-chain chlorinated paraffins. Anal Bioanal Chem 378(7):1741-7. https://doi.org/10.1007/s00216-004-2546-9

Schinkel L, Bogdal C, Canonica E, Cariou R, Bleiner D, McNeill K, Heeb NV (2018) Analysis of medium-chain and long-chain chlorinated paraffins: the urgent need for more specific analytical standards. Environ Sci Technol Lett 5:708-717. https://doi.org/10.1021/ acs.estlett. $8 \mathrm{~b} 00537$

Shang H, Fan X, Kubwabo C, Rasmussen PE (2019) Short-chain and medium-chain chlorinated paraffins in Canadian house dust and NIST SRM 2585. Environ Sci Pollut Res 26:7453-7462. https:// doi.org/10.1007/s11356-018-04073-2

Shi L, Gao Y, Zhang H, Geng N, Xu J, Zhan F, Ni Y, Hou X, Chen J (2017) Concentrations of short-and medium-chain chlorinated paraffins in indoor dusts from malls in China: implications for human exposure. Chemosphere 172:103-110. https://doi.org/10.1016/j. chemosphere.2016.12.150

Sibiya IV, Olukunle OI, Okonkwo OJ (2017) Seasonal variations and the influence of geomembrane liners on the levels of PBDEs in landfill leachates, sediment and groundwater in Gauteng Province, South Africa. Emerging Contam 3:76-84. https://doi.org/10.1016/j. emcon.2017.05.002

Sibiya I, Poma G, Cuykx M, Covaci A, Adegbenro PD, Okonkwo J (2019) Targeted and non-target screening of persistent organic pollutants and organophosphorus flame-retardants in leachate and sediment from landfill sites in Gauteng Province, South Africa. Sci Total Environ 653:1231-1239. https://doi.org/10.1016/j.scitotenv. 2018.10 .356

Sindiku O, Babayemi J, Osibanjo O, Schlummer M, Schluep M, Watson A, Weber R (2015) Polybrominated diphenyl ethers listed as Stockholm Convention POPs, other brominated flame retardants and heavy metals in e-waste polymers in Nigeria. Environ Sci Pollut Res 22:14489-14501. https://doi.org/10.1007/s11356-0143266-0

Sun R, Luo X, Tang B, Chen L, Liu Y, Mai B (2017) Bioaccumulation of short chain chlorinated paraffins in a typical freshwater food web contaminated by e-waste in south china: bioaccumulation factors, tissue distribution, and trophic transfer. Environ Pollut 222:165174. https://doi.org/10.1016/j.envpol.2016.12.060

Thomas GO, Farrar D, Braekevelt E, Stern G, Kalantzi OI, Martin FL, Jones KC (2006) Short and medium chain length chlorinated paraffins in UK human milk fat. Environ Int 32:34-40. https://doi.org/10. 1016/j.envint.2005.04.006

Tomy GT, Fisk AT, Westmore JB, Muir DC (1998) Environmental chemistry and toxicology of polychlorinated n-alkanes. In: Ware GW (ed) Reviews of environmental contamination and toxicology. Springer, New York, pp 53-128. https://doi.org/10.1007/978-14612-1708-4 2

UNDP (United Nations, Department of Economic and Social Affairs, Population Division) (2015) World population prospects: the 2015 revision. Key findings and advance tables. Available from: http:// esa.un.org/unpd/wpp/

UNEP (United Nations Environmental Programme) (2017) Draft guidance on preparing inventories of polychlorinated naphthalenes (PCNs)

UNEP (United Nations Environmental Programme) (2018) Draft technical guidelines on the environmentally sound management of wastes consisting of, containing or contaminated with short-chain chlorinated paraffins

UNEP (United Nations Environment Programme) (2019a) Detailed guidance on preparing inventories of short-chain chlorinated paraffins (SCCPs) Draft of 2019

UNEP (United Nations Environment Programme) (2019b) Plastic and toxic additives, and the circular economy: the role of the Basel and 
Stockholm Conventions. UNEP/CHW.14/INF/29/Add.1-UNEP/ POPS/COP.9/INF/28/Add.1

UNEP (United Nations Environmental Programme) (2019c) Technical guidelines, addendum general technical guidelines on the environmentally sound management of wastes consisting of, containing or contaminated with persistent organic pollutants

Vaccher V, Ingenbleek L, Adegboye A, Hossou SE, Koné AZ, Oyedele AD, Kisito CS, Dembélé YK, Hu R, Malak IA, Cariou R (2020) Levels of persistent organic pollutants (POPs) in foods from the first regional Sub-Saharan Africa Total Diet Study. Environ Int 135: 105413. https://doi.org/10.1016/j.envint.2019.105413

van Mourik LM, Leonards PE, Gaus C, de Boer J (2015) Recent developments in capabilities for analysing chlorinated paraffins in environmental matrices: a review. Chemosphere 136:259-272. https:// doi.org/10.1016/j.chemosphere.2015.05.045

van Mourik LM, Gaus C, Leonards PE, de Boer J (2016) Chlorinated paraffins in the environment: a review on their production, fate, levels and trends between 2010 and 2015. Chemosphere. 155: 415-428. https://doi.org/10.1016/j.chemosphere.2016.04.037

van Mourik LM, Toms LM, He C, Banks A, Hobson P, Leonards PE, de Boer J, Mueller JF (2020a) Evaluating age and temporal trends of chlorinated paraffins in pooled serum collected from males in Australia between 2004 and 2015. Chemosphere 244:125574. https://doi.org/10.1016/j.chemosphere.2019.125574

van Mourik LM, Wang X, Paxman C, Leonards PE, Wania F, de Boer J, Mueller JF (2020b) Spatial variation of short-and medium-chain chlorinated paraffins in ambient air across Australia. Environ Pollut 261:114141. https://doi.org/10.1016/j.envpol.2020.114141

Wang Y (2010) Polychlorinated naphthalenes and chlorinated paraffins in the atmosphere and soil in Dongiiang River catchment, South China. Dissertation, Guangzhou Institute of Geochemistry

Wang Y, Li J, Cheng Z, Li Q, Pan X, Zhang R, Liu D, Luo C, Liu X, Katsoyiannis A, Zhang G (2013) Short-and medium-chain chlorinated paraffins in air and soil of subtropical terrestrial environment in the Pearl River Delta, South China: distribution, composition, atmospheric deposition fluxes, and environmental fate. Environ Sci Technol 47:2679-2687. https://doi.org/10.1021/es304425r

Wang XT, Wang XK, Zhang Y, Chen L, Sun YF, Li M, Wu MH (2014) Short-and medium-chain chlorinated paraffins in urban soils of Shanghai: spatial distribution, homologue group patterns and ecological risk assessment. Sci Total Environ 490:144-152. https://doi. org/10.1016/j.scitotenv.2014.04.121

Wang X, Kennedy K, Powell J, Keywood M, Gillett R, Thai P, Bridgen P, Broomhall S, Paxman C, Wania F, Mueller JF (2015) Spatial distribution of selected persistent organic pollutants (POPs) in Australia's atmosphere. Enviro Sci Processes Impacts 17:525-532. https://doi.org/10.1039/C4EM00594E

Wang C, Gao W, Liang Y, Wang Y, Jiang G (2018a) Concentrations and congener profiles of chlorinated paraffins in domestic polymeric products in China. Environ Pollut 238:326-335. https://doi.org/10. 1016/j.envpol.2018.02.078

Wang P, Zhao N, Cui Y, Jiang W, Wang L, Wang Z, Chen X, Jiang L, Ding L (2018b) Short-chain chlorinated paraffin (SCCP) pollution from a CP production plant in China: dispersion, congener patterns and health risk assessment. Chemosphere 211:456-464. https://doi. org/10.1016/j.chemosphere.2018.07.136

Wang XT, Jia HH, Hu BP, Cheng HX, Zhou Y, Fu R (2019a) Occurrence, sources, partitioning and ecological risk of short-and medium-chain chlorinated paraffins in river water and sediments in Shanghai. Sci Total Environ 653:475-484. https://doi.org/10. 1016/j.scitotenv.2018.10.391

Wang X, Zhu J, Xue Z, Jin X, Jin Y, Fu Z (2019b) The environmental distribution and toxicity of short-chain chlorinated paraffins and underlying mechanisms: implications for further toxicological investigation. Sci Total Environ 695:133834. https://doi.org/10. 1016/j.scitotenv.2019.133834
Wang C, Gao W, Liang Y, Jiang Y, Wang Y, Zhang Q, Jiang G (2019c) Migration of chlorinated paraffins from plastic food packaging into food simulants: concentrations and differences in congener profiles. Chemosphere 225:557-564. https://doi.org/10.1016/j.chemosphere. 2019.03.039

Wang Y, Zhu X, Gao Y, Bai H, Wang P, Chen J, Yuan H, Wang L, Li X, Wang W (2019d) Monitoring gas-and particulate-phase short-chain polychlorinated paraffins in the urban air of Dalian by a selfdeveloped passive sampler. J Environ Sci 80:287-295. https://doi. org/10.1016/j.jes.2019.01.007

Wang X, Zhu J, Kong B, He B, Wei L, Jin Y, Shan Y, Wang W, Pan C, $\mathrm{Fu} Z$ (2019e) C9-13 chlorinated paraffins cause immunomodulatory effects in adult C57BL/6 mice. Sci Total Environ 675:110-121. https://doi.org/10.1016/j.scitotenv.2019.04.199

Wang K, Gao L, Zhu S, Cui L, Qiao L, Xu C, Huang D, Zheng M (2020a) Spatial distributions and homolog profiles of chlorinated nonane paraffins, and short and medium chain chlorinated paraffins in soils from Yunnan, China. Chemosphere 247:125855. https://doi.org/10. 1016/j.chemosphere.2020.125855

Wang W, Wang J, Nie H, Fan R, Huang Y (2020b) Occurrence, trophic magnification and potential risk of short-chain chlorinated paraffins in coral reef fish from the Nansha Islands, South China Sea. Sci Total Environ 739:140084. https://doi.org/10.1016/j.scitotenv. 2020.140084

Weber R, Watson A, Forter M, Oliaei F (2011) Persistent organic pollutants and landfills-a review of past experiences and future challenges. Waste Manag Res 29:107-121. https://doi.org/10.1177/ 0734242X10390730

Weber R, Herold C, Hollert H, Kamphues J, Ungemach L, Blepp M, Ballschmiter K (2018) Life cycle of PCBs and contamination of the environment and of food products from animal origin. Environ Sci Pollut Res 25:16325-16343. https://doi.org/10.1007/s11356018-1811-y

Wei GL, Liang XL, Li DQ, Zhuo MN, Zhang SY, Huang QX, Liao YS, Xie ZY, Guo TL, Yuan ZJ (2016) Occurrence, fate and ecological risk of chlorinated paraffins in Asia: a review. Environ Int 92:373387. https://doi.org/10.1016/j.envint.2016.04.002

Wong F, Suzuki G, Michinaka C, Yuan B, Takigami H, de Wit CA (2017) Dioxin-like activities, halogenated flame retardants, organophosphate esters and chlorinated paraffins in dust from Australia, the United Kingdom, Canada, Sweden and China. Chemosphere 168: 1248-1256. https://doi.org/10.1016/j.chemosphere.2016.10.074

Wu Y, Wu J, Tan H, Song Q, Zhang J, Zhong X, Zhou J, Wu W, Cai X, Zhang W, Liu X (2020) Distributions of chlorinated paraffins and the effects on soil microbial community structure in a production plant brownfield site. Environ Pollut 262:114328. https://doi.org/10. 1016/j.envpol.2020.114328

Wyatt I, Coutss CT, Elcombe CR (1993) The effect of chlorinated paraffins on hepatic enzymes and thyroid hormones. Toxicology 77:8190. https://doi.org/10.1016/0300-483x(93)90139-j

Xia D, Gao LR, Zheng MH, Li JG, Zhang L, Wu YN, Qiao L, Tian QC, Huang HT, Liu WB, Su GJ (2017a) Health risks posed to infants in rural China by exposure to short-and medium-chain chlorinated paraffins in breast milk. Environ Int 103:1-7. https://doi.org/10.1016/j. envint.2017.03.013

Xia D, Gao L, Zheng M, Li J, Zhang L, Wu Y, Tian Q, Huang H, Qiao L (2017b) Human exposure to short-and medium-chain chlorinated paraffins via mothers' milk in Chinese urban population. Environ Sci Technol 51:608-615. https://doi.org/10.1021/acs.est.6b04246

Xu C, Xu J, Zhang JB (2014) Emission inventory prediction of short chain chlorinated paraffins (SCCPs) in China. Acta Sci Nat Univ Pekin 50:369-378

Xu J, Gao Y, Zhang H, Zhan F, Chen J (2016) Dispersion of short-and medium-chain chlorinated paraffins (CPs) from a CP production plant to the surrounding surface soils and coniferous leaves. 
Environ Sci Technol 50:12759-12766. https://doi.org/10.1021/acs. est.6b03595

Xu C, Gao L, Zheng M, Qiao L, Cui L, Wang K, Huang D (2019a) Shortand medium-chain chlorinated paraffins in commercial rubber track products and raw materials. J Hazard Mater 380:120854. https://doi. org/10.1016/j.jhazmat.2019.120854

Xu C, Zhang Q, Gao L, Zheng M, Qiao L, Cui L, Wang R, Cheng J (2019b) Spatial distributions and transport implications of short-and medium-chain chlorinated paraffins in soils and sediments from an e-waste dismantling area in China. Sci Total Environ 649:821-828. https://doi.org/10.1016/j.scitotenv.2018.08.355

Xu J, Guo W, Wei L, Gao Y, Zhang H, Zhang Y, Sun M, Chen J (2019c) Validation of a HRGC-ECNI/LRMS method to monitor short-chain chlorinated paraffins in human plasma. J Environ Sci 75:289-295. https://doi.org/10.1016/j.jes.2018.04.004

Yang L, Wang Z, Li J, Ma Y, Kong L, Yang H, Wang L, Liu Y, Lu Y, Zhang J (2018) Evaluation of short chain chlorinated paraffins in human milk and their intake by infants in Hebei Province, China. Food Addit Contam Part A 35:2011-2021. https://doi.org/10.1080/ 19440049.2018.1492155

Yuan B, Wang T, Zhu N, Zhang K, Zeng L, Fu J, Wang Y, Jiang G (2012) Short chain chlorinated paraffins in mollusks from coastal waters in the Chinese Bohai Sea. Environ Sci Technol 46:64896496. https://doi.org/10.1021/es203839h

Yuan B, Fu J, Wang Y, Jiang G (2017a) Short-chain chlorinated paraffins in soil, paddy seeds (Oryza sativa) and snails (Ampullariidae) in an e-waste dismantling area in China: homologue group pattern, spatial distribution and risk assessment. Environ Pollut 220:608-615. https://doi.org/10.1016/j.envpol.2016.10.009

Yuan B, Strid A, Darnerud PO, de Wit CA, Nyström J, Bergman Å (2017b) Chlorinated paraffins leaking from hand blenders can lead to significant human exposures. Environ Int 109:73-80. https://doi. org/10.1016/j.envint.2017.09.014

Zeng L, Wang T, Han W, Yuan B, Liu Q, Wang Y, Jiang G (2011a) Spatial and vertical distribution of short chain chlorinated paraffins in soils from wastewater irrigated farmlands. Environ Sci Technol 45:2100-2106. https://doi.org/10.1021/es103740v

Zeng L, Wang T, Wang P, Liu Q, Han S, Yuan B, Zhu N, Wang Y, Jiang G (2011b) Distribution and trophic transfer of short-chain chlorinated paraffins in an aquatic ecosystem receiving effluents from a sewage treatment plant. Environ Sci Technol 45:5529-5535. https://doi. org/10.1021/es200895b

Zeng L, Zhao Z, Li H, Wang T, Liu Q, Xiao K, Du Y, Wang Y, Jiang G (2012) Distribution of short chain chlorinated paraffins in marine sediments of the East China Sea: influencing factors, transport and implications. Environ Sci Technol 46:9898-9906. https://doi.org/ $10.1021 / \mathrm{es} 302463 \mathrm{~h}$

Zeng L, Chen R, Zhao Z, Wang T, Gao Y, Li A, Wang Y, Jiang G, Sun L (2013a) Spatial distributions and deposition chronology of short chain chlorinated paraffins in marine sediments across the Chinese Bohai and Yellow Seas. Environ Sci Technol 47:11449-11456. https://doi.org/10.1021/es402950q

Zeng L, Li H, Wang T, Gao Y, Xiao K, Du Y, Wang Y, Jiang G (2013b) Behavior, fate, and mass loading of short chain chlorinated paraffins in an advanced municipal sewage treatment plant. Environ Sci Technol 47:732-740. https://doi.org/10.1021/es304237m

Zeng YH, Luo XJ, Tang B, Mai BX (2016) Habitat-and species-dependent accumulation of organohalogen pollutants in home-produced eggs from an electronic waste recycling site in South China: levels, profiles, and human dietary exposure. Environ Pollut 216:64-70. https://doi.org/10.1016/j.envpol.2016.05.039

Zeng L, Lam JC, Chen H, Du B, Leung KM, Lam PK (2017a) Tracking dietary sources of short-and medium-chain chlorinated paraffins in marine mammals through a subtropical marine food web. Environ Sci Technol 51:9543-9552. https://doi.org/10.1021/acs.est. $7 \mathrm{~b} 02210$

Zeng L, Lam JC, Horii Y, Li X, Chen W, Qiu JW, Leung KM, Yamazaki E, Yamashita N, Lam PK (2017b) Spatial and temporal trends of short-and medium-chain chlorinated paraffins in sediments off the urbanized coastal zones in China and Japan: a comparison study. Environ Pollut 224:357-367. https://doi.org/10.1016/j.envpol.2017. 02.015

Zhao N, Cui Y, Wang P, Li S, Jiang W, Luo N, Wang Z, Chen X, Ding L (2019) Short-chain chlorinated paraffins in soil, sediment, and seawater in the intertidal zone of Shandong Peninsula, China: distribution and composition. Chemosphere 220:452-458. https://doi.org/ 10.1016/j.chemosphere.2018.12.063

Zhou W, Shen M, Lam JC, Zhu M, Liu L, Chen H, Du B, Zeng L, Zeng EY (2018) Size-dependent distribution and inhalation exposure characteristics of particle-bound chlorinated paraffins in indoor air in Guangzhou, China. Environ Int 121:675-682. https://doi.org/10. 1016/j.envint.2018.10.004

Zhou X, Wu H, Huang X, Hang F, Luo H (2019) Development a simple and rapid HPLC-ESI-Q-TOF/MS method for determination of short-and medium-chain chlorinated paraffins in human serum. $\mathrm{J}$ Chromatogr B 1126:121722. https://doi.org/10.1016/j.jchromb. 2019.121722

Publisher's note Springer Nature remains neutral with regard to jurisdictional claims in published maps and institutional affiliations. 